\title{
Review
}

\section{Osmium complexes in catalysis of olefin hydrogenation and isomerization}

\author{
Giorgio Chelucci a,*, Gérard A. Pinna b , Giansalvo Pinna ${ }^{b}$, Maurizio Solinas c , Barbara Sechi c \\ a Dipartimento di Agraria, Università di Sassari, viale Italia 39, I-07100 Sassari, Italy \\ b Dipartimento di Chimica e Farmacia, Università di Sassari, Via F. Muroni 23/A, 07100 Sassari, Italy \\ c CNR, Istituto di Chimica Biomolecolare UOS Sassari, Traversa La Crucca 3, I-07100 Sassari, Italy
}

\section{A R T I C L E I N F O}

\section{Article history:}

Received 25 July 2016

Accepted 18 August 2016

Published 5 November 2016

\section{Keywords:}

Osmium complexes

Hydrogenation

Transfer hydrogenation

Alkene isomerization

Olefins

\begin{abstract}
A B S T R A C T
This review focuses on the evolution of the use of osmium complexes as catalysts in the hydrogenation and isomerization of olefins. Osmium systems show good catalytic activities and selectivities in the hydrogenation of olefins via both dihydrogen and transfer hydrogenation. Such systems therefore have significant potential to become a powerful tool in organic synthesis.
\end{abstract}

(C) 2016, Dalian Institute of Chemical Physics, Chinese Academy of Sciences. Published by Elsevier B.V. All rights reserved.

\section{Introduction}

The properties of osmium(II) complexes are similar to those of ruthenium(II) complexes and they can often be prepared using similar methods [1]. In a review of the use of osmium complexes in homogeneous catalysis [2], Sanchez-Delgado and coworkers pointed out that because of the stronger bonding of this $5 d$ metal compared with that of its $4 d$ counterpart, i.e., ruthenium, osmium-based catalysts have higher thermal and oxidative stabilities and therefore slower exchange kinetics for ligands typically involved in catalytic transformations. These factors have led to the general assumption that in the case of osmium the reactions involved in catalytic cycles, such as Lewis base addition-elimination and insertion-deinsertion, are too slow to be attractive for catalytic applications. These authors also suggested that this drawback could be overcome by choosing an appropriate ligand-metal system. This has recently been confirmed by the development of various osmium-based catalysts that show high performance and versatility in various processes and have efficiencies comparable or superior to those reported for similar ruthenium systems [3,4]; this compensates for the higher costs of osmium precursors compared with those of their analogs. However, despite the considerable progress that has been made in osmium-catalyzed reactions, their use in the hydrogenation and isomerization of alkenes has been neglected. In this review, we outline the evolution of the use of osmium complexes as catalysts in the hydrogenation and isomerization of alkenes, to stimulate research in this field.

\section{Mononuclear complexes}

The investigation of osmium hydrogenation catalysts began in 1965, when Vaska [5] reported preliminary observations on factors responsible for the catalytic hydrogenation of unsatu-

\footnotetext{
* Corresponding author. Tel: +39-079-229539; Fax:+39-079-229559; E-mail: chelucci@uniss.it

This work was supported by Fondazione di Sardegna.

DOI: 10.1016/S1872-2067(16)62542-1 | http://www.sciencedirect.com/science/journal/18722067 | Chin. J. Catal., Vol. 37, No. 11, November 2016
} 
rated molecules with metal complexes. It was reported that the octahedral hydride $d^{6}$-osmium complex OsHCl(CO)(PPh) 3 (1) catalyzes the hydrogenation of acetylene to ethylene and ethane. Experiments failed to detect hydrogen uptake by this complex $\left(40{ }^{\circ} \mathrm{C}, 0.92 \mathrm{~atm}\right.$ of $\left.\mathrm{H}_{2}\right)$; it reacted with molecular deuterium to give the corresponding monodeuteride, OsDCl$(\mathrm{CO})(\mathrm{PPh})_{3}$, but not the dideuteride, $\mathrm{OsD}_{2}(\mathrm{CO})(\mathrm{PPh})_{3}$.

Five years later, the Vaska osmium complex and a number of other metal complexes were assessed for the selective catalytic hydrogenation of 4-t-butylmethylenecyclohexane (2) [6]. After $2 \mathrm{~d}$ at $85^{\circ} \mathrm{C}$ under $1 \mathrm{~atm}$ of $\mathrm{H}_{2}, 1$ (0.05 mol\%) gave a mixture of cis- (3) and trans-4-t-butylmethylcyclohexane (4) (3:4 = $64: 36, \mathbf{3}+\mathbf{4}=14 \%$ yield) containing the isomerized alkene, 4-tert-butyl-1-methylcyclohex-1-ene (5) in 16\% yield (Scheme $1)$.

Shortly afterwards, a number of hydrido osmium complexes were prepared and assessed as catalysts in olefin hydrogenation and isomerization [7]. Reaction of the tetrahydride osmium complex $\mathrm{OsH}_{4}\left(\mathrm{PEtPh}_{2}\right)_{3}$ in the absence of $\mathrm{H}_{2}$ with 4 equiv. of cycloocta-1,5-diene in toluene at $100{ }^{\circ} \mathrm{C}$ for $65 \mathrm{~h}$ gave a $50 \%$ yield of cyclooctene and unreacted cyclooctadiene. The reaction of 12 equiv. of oct-1-ene under the same reaction conditions produced various octanes and 2 equiv. of octane. The same complex converted oct-1-ene under $1 \mathrm{~atm}$ of $\mathrm{H}_{2}$ in boiling toluene to octane and a large amount of isomerized products. The complex cis- $\mathrm{OsH}_{2}\left(\mathrm{PEtPh}_{2}\right)_{4}$ isomerized and hydrogenated oct-1-ene, indicating that more than two atoms of hydrogen per osmium atom are transferred to octane. This complex also catalyzed hydrogenation under $\mathrm{H}_{2}$, but the isomerization was much more rapid. Finally, $\mathrm{OsH}_{2}(\mathrm{CO})\left(\mathrm{PEtPh}_{2}\right)_{3}$ isomerized octenes in boiling toluene without the formation of octane; the isomerization of oct-2-ene was much slower than that of oct-1-ene. This complex gave only traces of hydrogenation products under $\mathrm{H}_{2}$; the rate of isomerization was similar to that without $\mathrm{H}_{2}$.

In a preliminary communication, Sánchez-Delgado and coworkers [8] described the use of the stable mononuclear osmium(II) complex OsHBr(CO) $\left(\mathrm{PPh}_{3}\right)_{3}$ (6; Scheme 2), which was first synthesized by Vaska [9] in 1964 via the reaction of $\left[\mathrm{OsBr}_{6}\right]^{2-}$ with $\mathrm{PPh}_{3}$ in refluxing 2-methoxyethanol, as a catalyst in various organic transformations, including alkene isomerization and hydrogenation reactions. Under an inert atmosphere, hex-1-ene was rapidly isomerized (30 $\mathrm{min}$ ) by 6 ([substrate]:[catalyst] $=100: 1)$ in toluene at $150{ }^{\circ} \mathrm{C}$, giving an equilibrium mixture of hex-2-enes; no $\mathrm{C}=\mathrm{C}$ bond migration to the 3-position was observed (Scheme 2). Under $1 \mathrm{~atm}$ of $\mathrm{H}_{2}$, hydrogenation of hex-1-ene to $n$-hexane was observed together with the formation of hex-2-enes, which were more slowly reduced to hexane. Further data on this isomeriza-

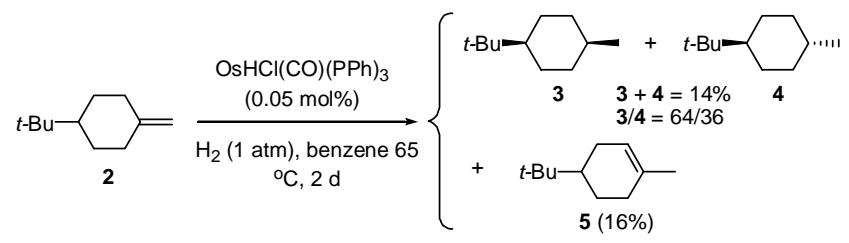

Scheme 1. Hydrogenation of 4-t-butylmethylenecyclohexane with osmium complex $\mathbf{1}$ [6].

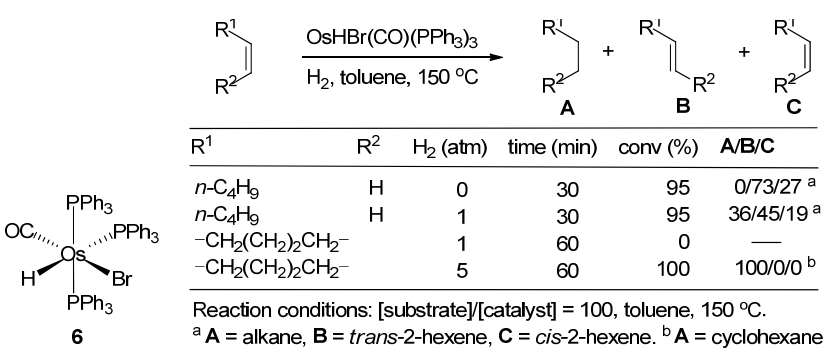

Scheme 2. Hydrogenation of hex-1-ene and cyclohexene with osmium complex 6 [8].

tion/reduction reaction were later reported by the same research group [10]. Under the same reaction conditions, but at $100{ }^{\circ} \mathrm{C}$, hex-1-ene (7) was rapidly isomerized to a mixture of trans- (8) and cis-hex-2-ene (9) (after 5 h, 7:8:9 = 11:65:24); no double-bond migration to the 3-position occurred, even after reaction for $24 \mathrm{~h}$. Under $\mathrm{H}_{2}$ at atmospheric pressure, hex-1-ene and trans-hex-2-ene were both isomerized to the same equilibrium mixture. Hydrogenation to $n$-hexane (10) occurred simultaneously, albeit at a much slower rate (after $5 \mathrm{~h}, \mathbf{7 : 8 : 9 : 1 0 =}$ $7: 51: 18: 24)$; at longer reaction times, $n$-hexane became the major product (after 16 h, 7:8:9:10 = 3:34:7:56). Complex 6 did not hydrogenate cyclohexene under $1 \mathrm{~atm}$ of $\mathrm{H}_{2}$, but rapid conversion to cyclohexane was achieved by increasing the $\mathrm{H}_{2}$ pressure to $5 \mathrm{~atm}$ (Scheme 2) [8]. The selective hydrogenation in toluene of the $\alpha, \beta$-unsaturated aldehyde crotonaldehyde afforded the saturated alcohol or the fully reduced product, depending on the reaction conditions (Table 1, entries 1 and 2) [8]. The same reduction in 2-ethoxyethanol solution was next studied using complex 6 and other osmium and ruthenium complexes (Table 1, entries 3-9) [11]. The results show that the ruthenium complexes gave high selectivities for $\mathrm{C}=\mathrm{C}$ bond reduction, whereas osmium complexes gave selective reduction of the $\mathrm{C}=\mathrm{O}$ bond.

The complex $\mathrm{OsHBr}(\mathrm{CO})\left(\mathrm{PPh}_{3}\right)_{3}$ was the first example of an active osmium-based catalytic system for the selective hydrogenation of conjugated and unconjugated dienes [10]. 1-Cyclohexa-1,3-diene (11) was isomerized under $\mathrm{N}_{2}$ to the deconjugated product cyclohexa-l,4-diene (12) (after $5 \mathrm{~h}$, 11:12 = 72:28), but at a slower rate than that observed for hex-1-ene. Under $1 \mathrm{~atm}$ of $\mathrm{H}_{2}$, hydrogenation of $\mathbf{1 1}$ gave the mono-olefin cyclohexene $\mathbf{1 3}$, the isomerized diene $\mathbf{1 2}$, and a small quantity of the fully hydrogenated product cyclohexane (14) (after 24 h, 11:12:13:14 = 37:18:42:3). Alkene 13 was slowly hydrogenated to alkane 14 under these reaction conditions (after $40 \mathrm{~h}, \mathbf{1 3 : 1 4}=83: 17$ ), but rapid reduction to 14 was achieved by raising the $\mathrm{H}_{2}$ pressure to $5 \mathrm{~atm}$. The activity of complex 6 was further investigated based on the hydrogenation of l-carvone (15), a model compound containing exocyclic and endocyclic $\mathrm{C}=\mathrm{C}$ bonds and a carbonyl group. As shown in Scheme 3 , the exocyclic $\mathrm{C}=\mathrm{C}$ bond in $\mathbf{1 5}$ was specifically reduced under $1 \mathrm{~atm}$ of $\mathrm{H}_{2}$ at $100{ }^{\circ} \mathrm{C}$ (30 turnovers in $24 \mathrm{~h}$ ). Raising the $\mathrm{H}_{2}$ pressure to $5 \mathrm{~atm}$ resulted in reduction of both $\mathrm{C}=\mathrm{C}$ bonds ( 65 turnovers in $5 \mathrm{~h}$ ), but the fully hydrogenated product, 2-methy1-5-(1-methylethyl)cyclohexanol, was not detected. 
Table 1

Hydrogenation of crotonaldehyde with osmium and ruthenium complexes [11].

\begin{tabular}{|c|c|c|c|c|c|c|c|}
\hline Entry & Complex & $T\left({ }^{\circ} \mathrm{C}\right)$ & Solvent & $\mathrm{H}_{2}$ (atm) & Time (min) & Conversion (\%) & $A / B / C$ \\
\hline 1 & $\mathrm{OsHBr}(\mathrm{CO})\left(\mathrm{PPh}_{3}\right)_{3}$ & 150 & Toluene & 5 & 30 & 35 & $20 / 15 / 65$ \\
\hline 2 & $\mathrm{OsHBr}(\mathrm{CO})\left(\mathrm{PPh}_{3}\right)_{3}$ & 100 & Toluene & 1 & 50 & 10 & $50 / 50 / 0$ \\
\hline 3 & $\mathrm{OsHBr}(\mathrm{CO})\left(\mathrm{PPh}_{3}\right)_{3}$ & 150 & 2-Ethoxyethanol & 5 & 15 & 36 & $30 / 22 / 48$ \\
\hline 4 & OsHBr(CO) $\left(\mathrm{PPh}_{3}\right)_{3}$ & 100 & 2-Ethoxyethanol & 1 & 50 & 40 & $50 / 50 / 0$ \\
\hline 5 & $\mathrm{OsCl}\left(\mathrm{OCOCH}_{3}\right)(\mathrm{CO})\left(\mathrm{PPh}_{3}\right)_{2}$ & 150 & 2-Ethoxyethanol & 5 & 15 & 32 & $66 / 34 / 0$ \\
\hline 6 & $\mathrm{RuHCl}(\mathrm{CO})\left(\mathrm{PPh}_{3}\right)_{3}$ & 150 & 2-Ethoxyethanol & 5 & 15 & 45 & $33 / 12 / 55$ \\
\hline 7 & $\mathrm{RuHCl}(\mathrm{CO})\left(\mathrm{PPh}_{3}\right)_{3}$ & 100 & 2-Ethoxyethanol & 1 & 15 & 35 & $86 / 14 / 0$ \\
\hline 8 & $\operatorname{RuBr}\left(\mathrm{OCOCH}_{3}\right)(\mathrm{CO})\left(\mathrm{PPh}_{3}\right)_{2}$ & 150 & 2-Ethoxyethanol & 5 & 15 & 48 & $42 / 6 / 52$ \\
\hline 9 & $\mathrm{RuH}\left(\mathrm{OCOCH}_{3}\right)(\mathrm{CO})\left(\mathrm{PPh}_{3}\right)_{2}$ & 100 & 2-Ethoxyethanol & 1 & 15 & 12 & $66 / 34 / 0$ \\
\hline
\end{tabular}

Reaction conditions: [substrate]/[catalyst] $=100$, toluene.

The cationic complex $\left[\mathrm{OsH}(\mathrm{CO})(\mathrm{NCMe})_{2}\left(\mathrm{PPh}_{3}\right)_{2}\right] \mathrm{BF}_{4}$ (20) was synthesized in high yield by reaction of the Vaska complex OsHCl(CO) $\left(\mathrm{PPh}_{3}\right)_{3}$ (19) with acetonitrile in the presence of $\mathrm{NaBF}_{4}$ (Scheme 4) [12]. These two complexes were assessed as catalysts in the hydrogenation of benzaldehyde, cyclohexanone, cyclohexene, and quinoline. Both complexes were efficient catalysts in the hydrogenation of cyclohexene (Table 2), and had higher activities than their ruthenium analogs. The results show that for some substrates complex $\mathbf{2 0}$ was a more efficient catalyst for the hydrogenations of $\mathrm{C}=\mathrm{C}$ and $\mathrm{C}=\mathrm{N}$ bonds than for $\mathrm{C}=\mathrm{O}$ bonds. This enhanced selectivity was rationalized in terms of a greater ability of this charged osmium complex to coordinate with $\mathrm{C}=\mathrm{C}$ and $\mathrm{C}=\mathrm{N}$ functional groups to an extent sufficient to promote subsequent hydrogen transfer.

More recently, the same research group found that osmium complex 20 was also an efficient catalyst for the selective reduction of 2-cyclohexen-1-one to cyclohexanone [13]. The reductions were performed under $4 \mathrm{~atm}$ of $\mathrm{H}_{2}$ at $100{ }^{\circ} \mathrm{C}$ for $7 \mathrm{~h}$ ([substrate $] /[$ complex $]=500$ ) in 2-methoxyethanol and toluene solutions (Scheme 5). Although previous reports suggested that chemoselective reduction $(\mathrm{C}=\mathrm{O}$ vs $\mathrm{C}=\mathrm{C})$ of the two functional groups in 2-cyclohexen-1-one using the analogous ruthenium complex $\left[\mathrm{RuH}(\mathrm{CO})(\mathrm{NCMe})_{2}\left(\mathrm{PPh}_{3}\right)_{2}\right] \mathrm{BF}_{4}$ as the catalyst

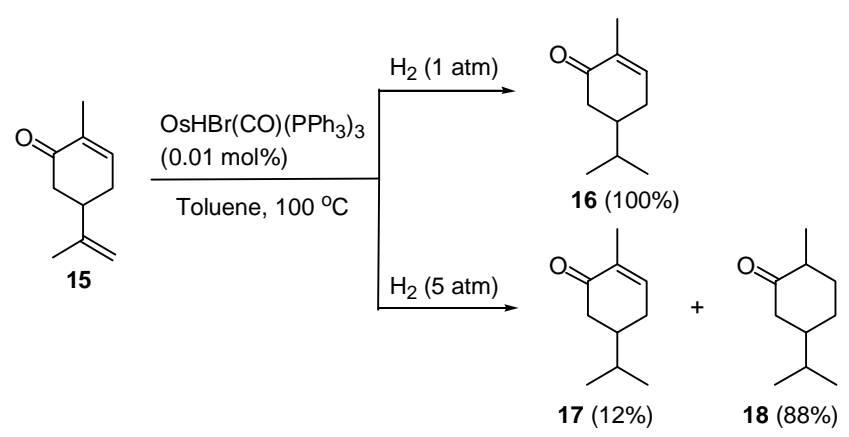

Scheme 3. Hydrogenation of l-carvone with osmium complex 6 [10].

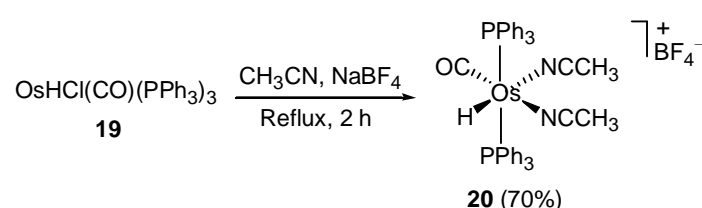

Scheme 4. Synthesis of osmium complex 20 [12]. depended on the solvent polarity [14], similar results were obtained using 20 in polar 2-methoxyethanol (60\% yield) and apolar toluene ( $65 \%$ yield). Reduction of the $\mathrm{C}=0$ group of cyclohexanone only began when the $\alpha, \beta$-unsaturated ketone had been consumed. Two main pathways have been proposed for the hydrogenation of 2-cyclohexen-1-one to cyclohexanone: (1) direct hydrogenation of the $\mathrm{C}=\mathrm{C}$ bond and (2) hydrogenation of the $\mathrm{C}=\mathrm{O}$ group of the substrate to produce 2-cyclohexen-1-ol, followed by isomerization to 1-cyclohexen-1-ol, which tautomerizes to cyclohexanone (Scheme 6). Experiments performed with 2-cyclohexen-1-ol to ascertain whether isomerization occurred indicated that the pathway involving isomerization (i.e., 2) could be ruled out.

Oro and coworkers [15] reported that OsHCl(CO) $\left(\mathrm{Pi}^{-} \mathrm{Pr}_{3}\right)_{2}$ (21) [16] added $\mathrm{H}_{2}$ to give $\mathrm{OsHCl}\left(\eta^{2}-\mathrm{H}_{2}\right)(\mathrm{CO})\left(\mathrm{Pi}^{-} \mathrm{Pr}_{3}\right)_{2}$ (22) under $1 \mathrm{~atm}$ of $\mathrm{H}_{2}$ in benzene at room temperature (Scheme 7). On removal of the $\mathrm{H}_{2}$ atmosphere under reduced pressure, complex 22 was slowly transformed back to the starting complex 21. Traces of $\mathrm{O}_{2}$ resulted in displacement of $\mathrm{H}_{2}$ from 22 to give $\mathrm{OsHCl}(\mathrm{CO})\left(\eta^{2}-\mathrm{O}_{2}\right)\left(\mathrm{Pi}^{-} \mathrm{Pr}_{3}\right)_{2}(23)$, which can also be formed by stirring a suspension of $\mathbf{2 1}$ in 2-propanol exposed to air or in an $\mathrm{O}_{2}$ atmosphere. Complex $\mathbf{2 2}$ catalyzed the hydrogenation of alkenes ([alkene] $/[22]=100,1 \mathrm{~atm}$ of $\left.\mathrm{H}_{2}, 60^{\circ} \mathrm{C}\right)$, but $\mathbf{2 1}$ gave

Table 2

Hydrogenation of cyclohexene with osmium complexes 19 and 20 [12].

\begin{tabular}{|c|c|c|}
\hline & $\frac{\text { Complexes } 19,20}{\mathrm{H}_{2} \text { (4 atm), xylene, } 100^{\circ} \mathrm{C}}$ & 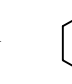 \\
\hline Catalyst $^{a}$ & & $\mathrm{TN}^{\mathrm{b}}$ \\
\hline 19 & & 191 \\
\hline 20 & & 167 \\
\hline
\end{tabular}

Scheme 5. Hydrogenation of 2-cyclohexen-1-one with osmium complex 20 [13]. 


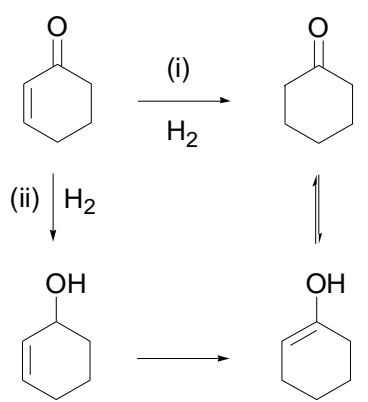

Scheme 6. Main pathways for hydrogenation of 2-cyclohexen-1-one with osmium complex 20 [13].

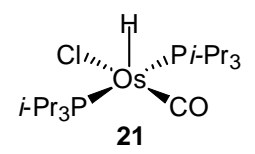<smiles>C=CC(C)=O</smiles>

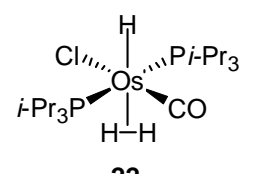

22

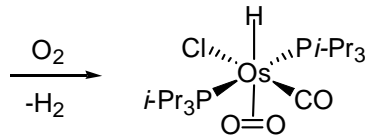

23
Scheme 7. Reactions of osmium complex 21 with $\mathrm{H}_{2}$ and $\mathrm{O}_{2}$ to give osmium complexes 22 and 23 [15].

no reaction. The hydrogenation rate depended on the solvent (for styrene: $\mathrm{PhH}<1,2-\mathrm{C}_{2} \mathrm{H}_{4} \mathrm{CI}_{2}<i$-PrOH) and on the olefin (in $i$-PrOH: benzylideneacetone $<$ cyclohexene $<$ styrene). Phenylacetylene was selectively reduced to styrene, and benzylideneacetone to benzylacetone; for cyclohexa-1,4-diene and diphenylacetylene [preferential formation of $(Z)$-stilbene] the selectivities were low. Kinetic studies indicated that a tris-hydrido(alkene)osmium or tris-hydrido(alkyne)osmium complex is formed as an intermediate, and gives an alkyl or vinyl species, respectively, via an insertion reaction.

Kinetic and mechanistic studies of the sequential hydrogenation of phenylacetylene catalyzed by $\operatorname{OsHCl}(\mathrm{CO})\left(\mathrm{PR}_{3}\right)_{2}$ $\left[\mathrm{PR}_{3}=\mathrm{Pi}-\mathrm{Pr}_{3}\right.$ (21) and PMet-Bu $\left.(24)\right]$ were reported [17]. These studies showed that complexes 21 and 24 efficiently catalyzed the sequential hydrogenation of phenylacetylene in 2-propanol solution at $60{ }^{\circ} \mathrm{C}$ under $1 \mathrm{~atm}$ of $\mathrm{H}_{2}$, affording selectivities close to $100 \%$ for hydrogenation of the alkyne to the alkene. Reduction of the double bond only began when most of the alkyne had been consumed. In the absence of an alkyne, styrene was hydrogenated to ethylbenzene at faster rate than that observed for reduction of the acetylenic triple bond. No reduction of the organic substrates was observed in 2-propanol under argon, showing that hydrogen transfer from the solvent is not an important catalytic pathway.

The six-coordinate diamagnetic osmium(IV) complexes $\mathrm{OsH}_{2} \mathrm{Cl}_{2}\left(\mathrm{PR}_{3}\right)_{2}\left[\mathrm{PR}_{3}=\mathrm{Pi}_{-} \mathrm{Pr}_{3}(\mathbf{2 5})\right.$ and $\mathrm{PMet}-\mathrm{Bu}_{2}$ (26)] were prepared from $\mathrm{OsCl}_{3} \cdot x \mathrm{H}_{2} \mathrm{O}$ and $\mathrm{PR}_{3}$ in boiling 2-propanol in about $80 \%$ yield (Scheme 8) [18]. The crystal structure of complex 25 was determined. Treatment of complex 26 with CO led to reductive elimination of $\mathrm{H}_{2}$ and formation of
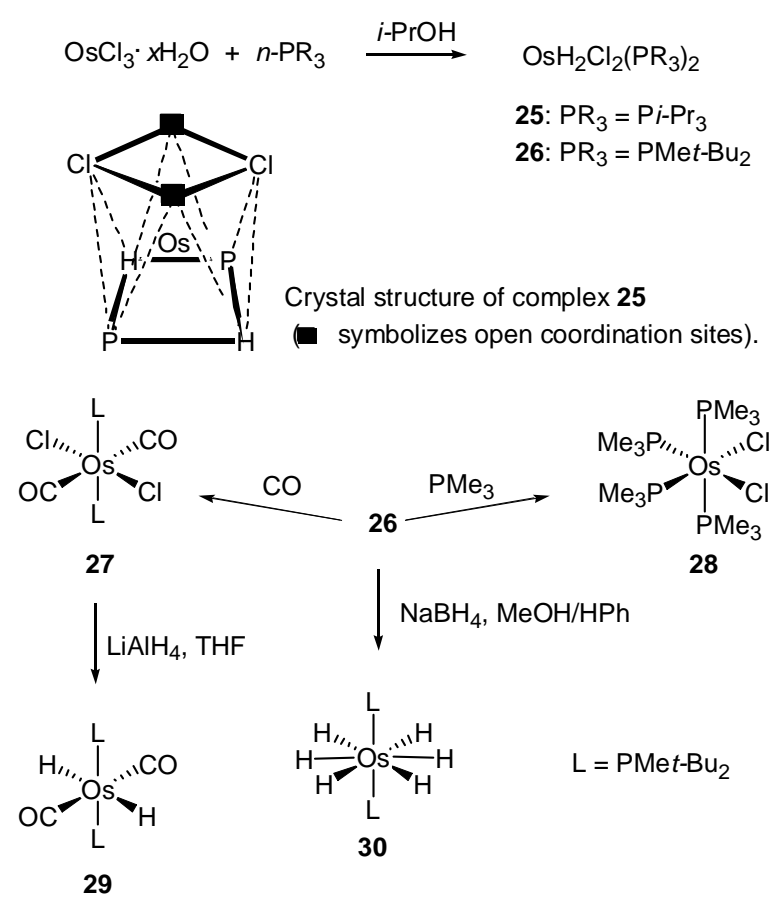

Scheme 8. Synthesis of osmium complexes 27-30 from osmium complex 26 [18].

all-trans-OsCl ${ }_{2}(\mathrm{CO})_{2}\left(\mathrm{PMe} \text { - }-\mathrm{Bu}_{2}\right)_{2}$ (27). Similarly, complex 26 reacted with excess $\mathrm{PMe}_{3}$ to give cis-O $\mathrm{OsCl}_{2}\left(\mathrm{PMe}_{3}\right)_{4}$ (28). The reaction of complex 27 with $\mathrm{LiAIH}_{4}$ in tetrahydrofuran led to the formation of all-trans- $\mathrm{OsH}_{2}(\mathrm{CO})_{2}\left(\mathrm{PMet}_{-} \mathrm{Bu}_{2}\right)_{2}$ (29), whereas treatment of $\mathbf{2 5}$ and $\mathbf{2 6}$ with $\mathrm{NaBH}_{4}$ in methanol/benzene afforded the hexahydrido complexes $\mathrm{OsH}_{6}\left(\mathrm{PR}_{3}\right)_{2} \mathbf{3 0}$ in about $60 \%$ yields. Under $1 \mathrm{~atm}$ of $\mathrm{H}_{2}$ at $60{ }^{\circ} \mathrm{C}$, solutions of 25 in 2-propanol, 1,2-dichloroethane, or toluene $\left([25]=2.5 \times 10^{-3}\right.$ $\mathrm{mol} / \mathrm{L}$, [olefin] $/[25]=100$ ) catalyzed the hydrogenations of styrene, methylstyrene, cyclohexene, and cyclooctene at considerable initial rates. The initial rate $v_{0}$ depended both on the solvent (for cyclooctene: $v_{0}[i-\mathrm{PrOH}]>v_{0}[\mathrm{MePh}]>$ $\left.v_{0}\left[1,2-\mathrm{Cl}_{2} \mathrm{C}_{2} \mathrm{H}_{4}\right]\right)$ and the olefinic substrate (in $i$-PrOH: cyclooctene $>$ styrene $>$ cyclohexene $>$ methylstyrene). Dienes and $\alpha, \beta$-unsaturated ketones were also hydrogenated by complex 25. Cycloocta-1,5-diene was more rapidly reduced than the 1,3-isomer. This finding was also true in a competitive sense: cycloocta-l,3-diene was not hydrogenated until the concentration of the 1,5-isomer was almost zero. However, for these reactions, selectivity for the mono-olefin was poor. In contrast, benzylideneacetone and benzylideneacetophenone were reduced to the saturated ketones with high selectivities.

Bianchini and coworkers [19] reported that the hydride complexes $\left[\mathrm{M}(\mathrm{H})\left(\eta^{2}-\mathrm{H}_{2}\right)\left(\mathrm{PP}_{3}\right)\right] \mathrm{BPh}_{4}\left[\mathrm{M}=\mathrm{Fe}, \mathrm{Ru}, \mathrm{Os} ; \mathrm{PP}_{3}=\right.$ $\left.\mathrm{P}\left(\mathrm{CH}_{2} \mathrm{CH}_{2} \mathrm{PPh}_{2}\right)_{3}\right]$ were efficient catalysts for the reduction of $\alpha, \beta$-unsaturated ketones via hydrogen transfer from 2-propanol at $80{ }^{\circ} \mathrm{C}$. The iron and ruthenium complexes reduced $\alpha, \beta$-unsaturated ketones to allylic alcohols, whereas the osmium system $\left[\mathrm{OsH}\left(\mathrm{H}_{2}\right)\left(\mathrm{P}\left(\mathrm{CH}_{2} \mathrm{CH}_{2} \mathrm{PPh}_{2}\right)_{3}\right)\right] \mathrm{BPh}_{4}$ (31) afforded saturated ketones via isomerization of the initially produced allylic alcohols. Acyclic $\alpha, \beta$-unsaturated ketones were reduced with good catalytic activity to give the corresponding saturated 
ketones, which were subsequently reduced to saturated alcohols (Table 3). Cyclic $\alpha, \beta$-unsaturated ketones were also reduced, but in this case the product distribution depended on both the ring size and steric hindrance around the reducible groups. Complex $\mathbf{3 1}$ did not catalyze reactions of simple olefins or olefins activated by electron-withdrawing groups, except in the reaction with methyl cinnamate, in which traces of the reduction product were detected. A mechanism for the isomerization of allylic alcohols to saturated ketones catalyzed by osmium complex 31 was proposed (Scheme 9) based on the results of a number of experiments.

In a series of papers, Rempel and coworkers [20] reported studies of the activities of a number of osmium complexes as catalysts for the hydrogenation of diene-based polymers and

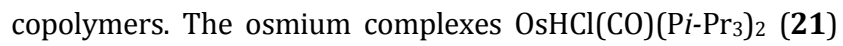
and $\mathrm{OsHCl}(\mathrm{CO})\left(\mathrm{PR}_{3}\right)_{2}$ 32a-d $\left(\mathrm{PR}_{3}=\mathbf{a}: \mathrm{PPh}_{3}\right.$, b: $\mathrm{P}\left(3-\mathrm{MeC}_{6} \mathrm{H}_{4}\right)_{3}$, $\mathbf{c}$ : $\mathrm{PCy}_{3}, \mathbf{d}: \mathrm{PCy}_{2} \mathrm{Ph}$ ) were prepared by reacting $\mathrm{OsCl}_{3} \cdot 3 \mathrm{H}_{2} \mathrm{O}$ with the appropriate phosphine in methoxyethanol under reflux. OsHCl$(\mathrm{CO})\left(\eta^{2}-\mathrm{O}_{2}\right)\left(\mathrm{Pi}^{-} \mathrm{Pr}_{3}\right)_{2}$ (23) and $\mathrm{OsHCl}(\mathrm{CO})\left(\eta^{2}-\mathrm{O}_{2}\right)\left(\mathrm{PR}_{3}\right)_{2}$ 33c and $\mathbf{d}\left(\mathrm{PR}_{3}=\mathbf{c}: \mathrm{PCy}_{3}, \mathbf{d}: \mathrm{PCy}{ }_{2} \mathrm{Ph}\right)$ were obtained by exposing a suspension of complexes $\mathbf{2 1}$ and 32c or $\mathbf{d}$ in hexane to pure $\mathrm{O}_{2}$. OsHCl$(\mathrm{CO})\left(\mathrm{PPh}_{3}\right)(\mathrm{dppp})\left(\mathbf{3 4} ; \mathrm{dppp}=\mathrm{Ph}_{2} \mathrm{P}\left(\mathrm{CH}_{2}\right)_{3} \mathrm{PPh}_{2}\right)$ was obtained by reacting complex 32a with dppp in refluxing $p$-xylene (Scheme 10).

Rempel's group reported that the osmium(II) complexes $\mathrm{OsHCl}(\mathrm{CO})(\mathrm{L})\left(\mathrm{PCy}_{3}\right)_{2}\left(\mathrm{~L}=\right.$ vacant $32 \mathrm{c}$ and $\mathrm{O}_{2}$ 33c) were efficient catalysts for the selective hydrogenation of acrylonitrile-butadiene rubber (NBR) (Scheme 11) [21]. These catalysts were more active under industrial conditions (pressure $>$ 20 atm, temperature $>100{ }^{\circ} \mathrm{C}$ ) than rhodium-, ruthenium-, and palladium-based systems [22-24]. A detailed study of their catalytic behaviors under hydrogenation conditions approaching those used industrially was later reported [25].

Scheme 12 shows the structures and reactivities of the $\mathrm{O}_{2}$,

Table 3

Hydrogen transfer reduction of $\alpha, \beta$-unsaturated ketones catalyzed by osmium complex 31 [19].

\begin{tabular}{|c|c|c|c|c|c|}
\hline Substrate & $\begin{array}{l}\text { Time } \\
\text { (h) }\end{array}$ & $\begin{array}{c}\text { Conv. } \\
(\%)\end{array}$ & $\begin{array}{c}\text { Saturated } \\
\text { ketone (\%) }\end{array}$ & $\begin{array}{c}\text { Saturated } \\
\text { alcohol (\%) }\end{array}$ & $\begin{array}{l}\text { Unsaturated } \\
\text { alcohol (\%) }\end{array}$ \\
\hline & 3 & 91 & 72 & 10 & 9 \\
\hline & 3 & 93 & 64 & 29 & 0 \\
\hline & 7 & 11 & 11 & 0 & 0 \\
\hline & 8 & 100 & 95 & 5 & 0 \\
\hline & 3 & 91 & 9 & 77 & 5 \\
\hline & 7 & 43 & 0 & 6 & 37 \\
\hline & 7 & 2 & 0 & 0 & 2 \\
\hline & 1 & 98 & 84 & 1 & 0 \\
\hline & 7 & 2 & 2 & 4 & 0 \\
\hline
\end{tabular}

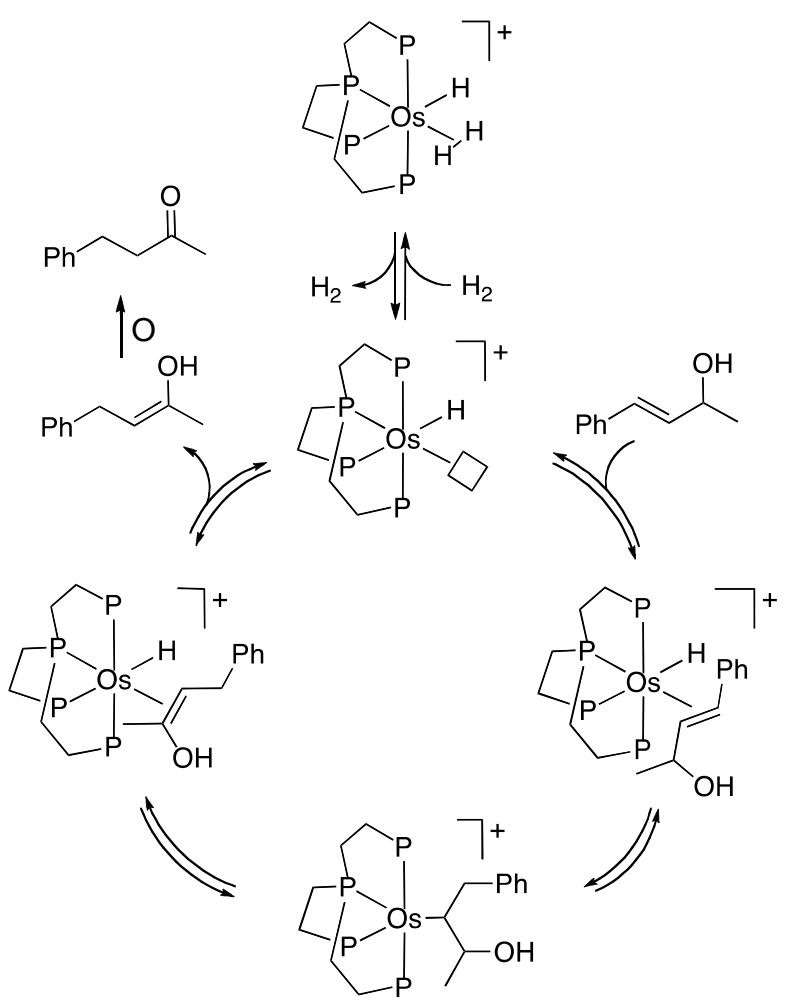

Scheme 9. Mechanism of isomerization of allylic alcohols to saturated ketones with osmium complex 31 [19].

$\mathrm{PhCN}$, and $\mathrm{H}_{2}$ complexes 32c, 35, and 36, which were investigated in that study. Complex 33c, which was used as a catalyst precursor, was activated by $\mathrm{O}_{2}$ dissociation to generate the related five-coordinate complex 32c [26]. Because of its coordinative unsaturation, small Lewis bases readily added to complex 32c to form isolable complexes such as the nitrile adduct 35. $\mathrm{H}_{2}$ added to the metal center by $\eta^{2}$-coordination, with the $\mathrm{H}-\mathrm{H}$ bond remaining intact, to give complex 36. The predominant osmium complexes formed during NBR hydrogenation under $23.7 \mathrm{~atm}$ of $\mathrm{H}_{2}$ at $130{ }^{\circ} \mathrm{C}$ were the dihydrogen and nitrile complexes $\mathbf{3 5}$ and $\mathbf{3 6}$.

The process was first order with respect to [Os], implying that the active complex is mononuclear. Nitrile and phosphine ligands both reduced the catalytic activity: nitrile by coordination to the metal center and phosphine presumably by inhibi-

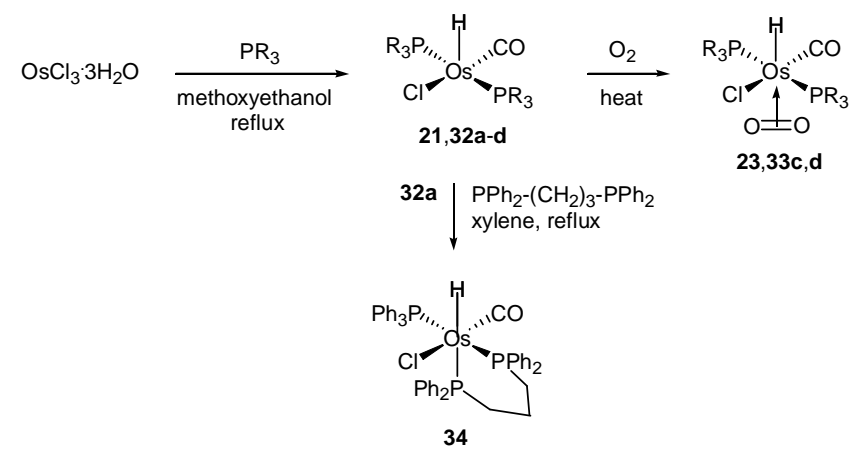

$\mathrm{PR}_{3}: \mathbf{a}=\mathrm{PPh}_{3}, \mathbf{b}=\mathrm{P}\left(3-\mathrm{MeC}_{6} \mathrm{H}_{4}\right)_{3}, \mathbf{c}=\mathrm{PCy}_{3}, \mathbf{d}=\mathrm{PCy}_{2} \mathrm{Ph}, \mathbf{2 3}=\mathrm{P}(i-\mathrm{Pr})_{3}$

Scheme 10. Synthesis of osmium complexes $21,23,32 a-d, 33 c$ and $d$, and 34 [20]. 


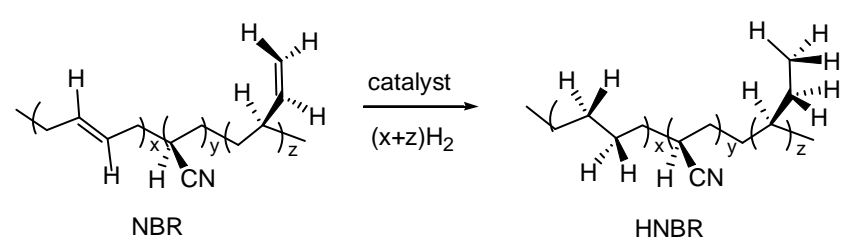

Scheme 11. Structures of NBR and its hydrogenated product HNBR [20].

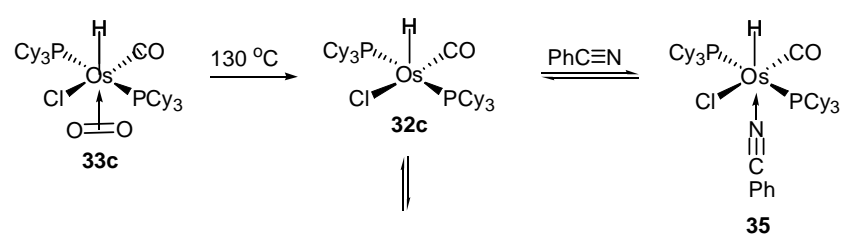

$$
\begin{aligned}
& \mathrm{Cy}_{3} \mathrm{P}_{\prime \prime \prime} \overbrace{\mathrm{N}} \mathrm{CO} \\
& 36
\end{aligned}
$$

Scheme 12. Synthesis of osmium complexes 32c, 35, and 36 from osmium complex 33c [26].

tion of a required dissociation reaction. Nitrile coordination induced second-order dependence of the reaction rate with respect to $\mathrm{H}_{2}$; the effect was less at high pressures. In contrast, the hydrogenation of substrates lacking a nitrile functionality was unaffected by $\mathrm{H}_{2}$ at all pressures. These kinetic measurements, coupled with other observations, provide the basis of a plausible reaction mechanism, in which two molecules of $\mathrm{H}_{2}$ are involved in the rate-limiting reaction (Scheme 13) [27].

The NBR hydrogenation selectivities of osmium complexes 21, 23, 32a-d, 33c and d, and 34 were investigated [20]. These complexes were divided into three classes, based on correlations between the phosphine ligand properties and catalytic activities of the complexes: (1) class I: complexes containing bulky monophosphines with a Tolman's cone angle $\geq 160^{\circ}(\mathbf{2 3}$, 32c and d, and 33c and d); (2) class II: complexes containing small monophosphines (32a and b); and (3) class III: complexes containing diphosphines (34). The activities of these complexes generally decreased in the order: class I > class II > class III. This trend was mainly attributed to the ease of dissociation of a ligand from an 18-electron complex to generate a 16-electron species $\left(\mathrm{O}_{2}>\mathrm{PR}_{3}>\mathrm{dppp}\right)$ in the catalytic process. The catalytic activities of class I complexes increased as follows: $\mathrm{PCy}_{2} \mathrm{Ph} \ll \mathrm{Pi}-\mathrm{Pr}_{3}<\mathrm{PCy}_{3}$. This trend does not correlate with the steric effects, based on Tolman's cone angles, but it is in good agreement with electronic effects, which were evaluated based on the infrared (IR) vo values of these complexes. The catalytic activities of these complexes increased with decreasing $v_{\text {co }}$ value, which is consistent with the increase in the donor power of the phosphine ligands. This indicates that the activities of these complexes predominately depend on the electronic properties of the phosphines; based on this and the kinetic isotope effect, the rate-determining step in the catalytic process would be $\mathrm{H}_{2}$ bond cleavage or olefin insertion into an Os-H bond. For classes II and III, complexes containing bulky, strong $\sigma$-donor and weak $\pi$-acceptor phosphines were good catalysts, whereas the presence of a chelating phosphine ligand

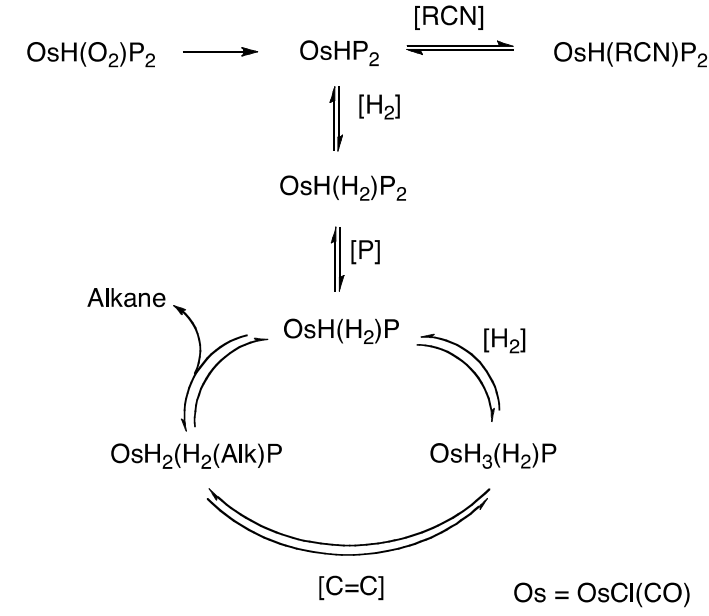

Scheme 13. Proposed catalytic cycles involved in hydrogenation of NBR to hydrogenated $\mathrm{HNBR}$ using $\mathrm{OsHCl}(\mathrm{CO})\left(\eta^{2}-\mathrm{O}_{2}\right)\left(\mathrm{PCy}_{3}\right)_{2}$ [27].

resulted in a poor catalyst.

The catalytic activities of a number of catalysts, namely $\mathrm{RhCl}\left(\mathrm{PPh}_{3}\right)_{3}, \quad \mathrm{RuCl}(\mathrm{CO})\left(\right.$ styryl)(PCy3)2, $\quad\left[\operatorname{Ir}(\mathrm{COD}) \mathrm{py}\left(\mathrm{PCy}_{3}\right)\right] \mathrm{PF} 6$, and OsHCl(CO) $\left(\eta^{2}-\mathrm{O}_{2}\right)\left(\mathrm{PCy}_{3}\right)_{2}(33 \mathrm{c})$, in the homogeneous hydrogenation of cis-1,4-poly(isoprene) (CPIP) were investigated by monitoring the amount of $\mathrm{H}_{2}$ consumed during the reaction (Scheme 14) [27]. The osmium complex was the most efficient. Kinetic experiments on $\mathrm{OsHCl}(\mathrm{CO})\left(\eta^{2}-\mathrm{O}_{2}\right)\left(\mathrm{PCy}_{3}\right)_{2}$-catalyzed CPIP hydrogenation in toluene under 3.4-68 atm of $\mathrm{H}_{2}$ at $115-140{ }^{\circ} \mathrm{C}$ indicated that the hydrogenation rate was first order with respect to the catalyst and the $\mathrm{C}=\mathrm{C}$ bond concentration. A second-order dependence on $\mathrm{H}_{2}$ concentration for low values and zero order dependence for higher values of $\mathrm{H}_{2}$ concentration were observed. The apparent activation energy for CPIP hydrogenation in the temperature range $115-140{ }^{\circ} \mathrm{C}$ was $109.3 \mathrm{~kJ} / \mathrm{mol}$. Investigation of the mechanism of this catalytic process showed that the catalytic cycle is the same as that proposed for NBR hydrogenation (Scheme 13) [25].

The homogeneous complex 33c was also reported to be an efficient catalyst precursor for the hydrogenation of natural rubber latex (NRL) under 2-68 atm of $\mathrm{H}_{2}$ at $125-145{ }^{\circ} \mathrm{C}$ in chlorobenzene, providing an alternating ethylene-propylene copolymer (Scheme 15) [28,29]. Kinetic data showed the effects of the catalyst and polymer concentrations, $\mathrm{H}_{2}$ pressure, and reaction temperature on the catalytic activity. The hydrogenation reaction was first order with respect to catalyst concentration, which implies that the active complex was a mononuclear species. The hydrogenation rate showed first-order dependence on $\mathrm{H}_{2}$, but this changed to zero-order dependence at low $\mathrm{H}_{2}$ pressures, and inverse $\mathrm{H}_{2}$ dependence at high $\mathrm{H}_{2}$ pressures. The hydrogenation rate depended on the reaction temperature, and the apparent activation energy in the temperature range $125-145{ }^{\circ} \mathrm{C}$ was $122.76 \mathrm{~kJ} / \mathrm{mol}$. A mechanism

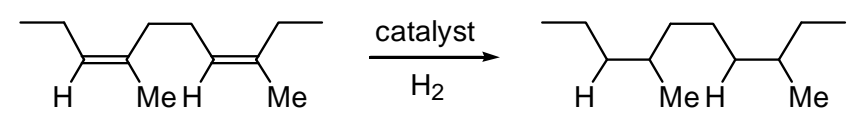

Scheme 14. Hydrogenation of CPIP with $\mathrm{OsHCl}(\mathrm{CO})\left(\eta^{2}-\mathrm{O}_{2}\right)\left(\mathrm{PCy}_{3}\right)_{2}(33 \mathrm{c}$ [27]. 
for the hydrogenation of natural rubber in the presence of OsHCl$(\mathrm{CO})\left(\eta^{2}-\mathrm{O}_{2}\right)\left(\mathrm{PCy}_{3}\right)_{2}$ was proposed on the basis of the kinetic results.

Complex 33c was an efficient catalyst for hydrogenation of a styrene- $g$-natural rubber copolymer (ST- $g$-NR) under 6.7-78 atm of $\mathrm{H}_{2}$ at $120-160{ }^{\circ} \mathrm{C}$ in chlorobenzene [30]. Univariate experiments were conducted to explore the effects of variables on the rate of hydrogenation; the $\mathrm{H}_{2}$ consumption as a function of time was measured using a gas-uptake apparatus. The kinetic results showed that ST- $g$-NR hydrogenation was first-order with respect to $[\mathrm{C}=\mathrm{C}]$. The hydrogenation rate showed first-order dependence on the catalyst concentration. The reaction showed first-order dependence on $\mathrm{H}_{2}$ pressure, changing to zero-order dependence with increasing $\mathrm{H}_{2}$ pressure. The rate of hydrogenation also decreased with increasing rubber concentration. The addition of a small amount of acid increased the hydrogenation rate of the grafted natural rubber. The ST- $g$-NR hydrogenation rate depended on the reaction temperature, and the apparent activation energy in the range 120-160 ${ }^{\circ} \mathrm{C}$ was $83.3 \mathrm{~kJ} / \mathrm{mol}$.

Sanchez-Delgado and coworkers [31] synthesized three water-soluble complexes, $\mathrm{OsH}_{4}(\mathrm{TPPMS})_{3} \quad$ (37), $\mathrm{OsHCl} \mathrm{CO}(\mathrm{TPPMS})_{2} \quad$ (38), and $\left[\mathrm{OsCl}(\mathrm{TPPMS})_{2}(\mu-\mathrm{Cl})\right]_{2} \quad$ (39) (TPPMS $=m$-sulfonatophenyldiphenyldiphosphine), as shown in Scheme 16. These complexes and mixtures of osmium salts with TPPMS and TPPTS (tris- $m$-sulfonatophenylphosphine) catalyzed the hydrogenation of cinnamaldehyde under mild reaction conditions in aqueous biphasic systems (Table 4). The activities and selectivities of these catalysts were compared with those of the homogeneous $\mathrm{PPh}_{3}$ analogs (Table 4). In the examined series, a combination of $\mathrm{OsCl}_{3} \cdot 3 \mathrm{H}_{2} \mathrm{O}$ with 6 equiv. of $\mathrm{PPh}_{3}$ provided the best homogeneous catalytic system for the regioselective reduction of the $\mathrm{C}=0$ bond of cinnamaldehyde. The regioselectivity for production of the $\alpha, \beta$-unsaturated alcohol increased significantly on changing from a homogeneous to a biphasic system; $\mathrm{OsCl}_{3} \cdot 3 \mathrm{H}_{2} \mathrm{O}$ with TPPMS or, better still, TPPTS gave the best aqueous biphasic systems.

The authors proposed a mechanism for the hydrogenation of cinnamaldehyde with the in situ-prepared catalyst, involving a reasonable set of reactions that lead to the active species participating in the catalytic cycle (Scheme 17) [31].. The complex $\mathrm{OsCl}_{3} \cdot 3 \mathrm{H}_{2} \mathrm{O}$ first reacts with TPPMS to yield the dimer $\left.\left[\mathrm{OsCl}_{2} \text { (TPPMS }\right)_{2}\right]_{2}$, which is then transformed into [OsHCl(TPPMS $\left.)_{2}\right]_{2}$ by reaction with $\mathrm{H}_{2}$; a bridge-splitting reaction with a substrate molecule (Subs) generates the monomeric intermediate $\mathrm{OsHCl}(\mathrm{TPPMS})_{2}$ (Subs), in which the unsaturated aldehyde can be coordinated through the $\mathrm{C}=\mathrm{C}$ bond or the $\mathrm{C}=\mathrm{O}$ bond. This provides entries into two catalytic cycles ( $\mathbf{A}$ and $\mathbf{B}$ ), leading to the saturated aldehyde (Pr1) and the unsaturated alcohol (Pr2), respectively, probably via a standard series of elementary steps (oxidative addition of $\mathrm{H}_{2}$, stepwise transfer of hydride to the unsaturated bond, and reductive elimination of

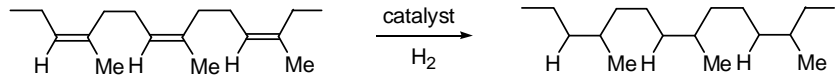

Scheme 15. NRL hydrogenation to give alternating ethylene-propylene copolymer [28,29].

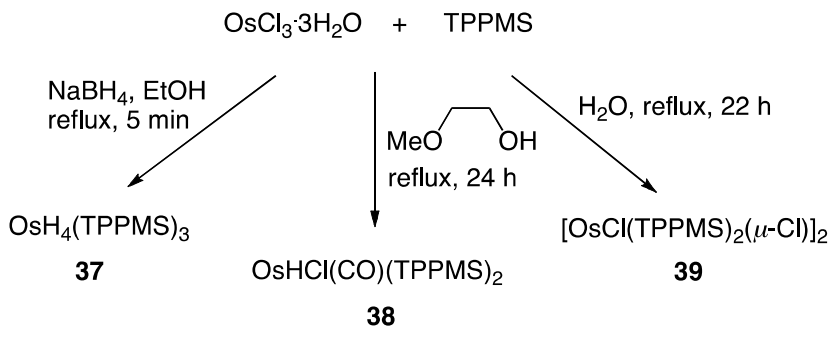

Scheme 16. Synthesis of osmium complexes 37-39 [31].

the products). At low substrate concentration the reaction selectivity depends on the ability of the catalyst to form the species in the cycle $\mathbf{A}$ or $\mathbf{B}$ in the mixture. If the substrate concentration is high, two molecules can bind to the metal atom; in this case, for steric reasons, end-on coordination through the $\mathrm{C}=\mathrm{O}$ bond is favored over side-on $\mathrm{C}=\mathrm{O}$ or $\mathrm{C}=\mathrm{C}$ coordination, leading to higher selectivity for the unsaturated alcohol through the third catalytic cycle C (Scheme 17). High selectivity effects are observed on switching from homogeneous to biphasic catalysts because the more hydrophilic $\mathrm{C}=0$ bond points toward the aqueous phase, in which the metal center is located, whereas the hydrophobic $\mathrm{C}=\mathrm{C}$ bond points away from the aqueous phase and into the organic layer, favoring the formation of the species in $\mathbf{B}$ and $\mathbf{C}$ over $\mathbf{A}$.

The reactions of $\left[\mathrm{OsCl}(m-\mathrm{Cl})\left(\eta^{6}-p \text {-cymene }\right)\right]_{2}$ (39) with phosphites or tert-butylisocyanide gave the $p$-cymene complexes $\mathrm{OsCl}_{2}\left(\eta^{6}-p\right.$-cymene $) \mathrm{L} \quad \mathbf{4 0 a}-\mathbf{c}\left[\mathrm{L}=\mathbf{a}: \mathrm{P}(\mathrm{OEt})_{3}, \mathbf{b}\right.$ : $\mathrm{PPh}(\mathrm{OEt}) 2$, c: tert-BuNC], as shown in Scheme 18 [32]. Treatment of complexes $\mathbf{4 0 a}$ and $\mathbf{b}$ with the triazines 1,3-ArN=NN(H)Ar ( $\mathrm{Ar}=\mathrm{Ph}$ and $p$-tolyl $)$ and excess $\mathrm{NEt}_{3}$ afforded the cationic triazenide derivatives [Os( $\left.\eta^{2}-1,3-A r N N N A r\right)\left(\eta^{6}-p\right.$ cymene $\left.) \mathrm{L}\right] \mathrm{BPh}_{4} 41[\mathrm{Ar}=\mathrm{Ph}, \mathrm{L}=$ $\left.\mathrm{PPh}(\mathrm{OEt})_{2}\right]$ and 42a and $\mathbf{b}\left[\mathrm{Ar}=p\right.$-tolyl, $\mathrm{L}=\mathrm{PPh}(\mathrm{OEt})_{2}$ or

Table 4

Hydrogenation of cinnamaldehyde using homogeneous and biphasic osmium catalysts [31].

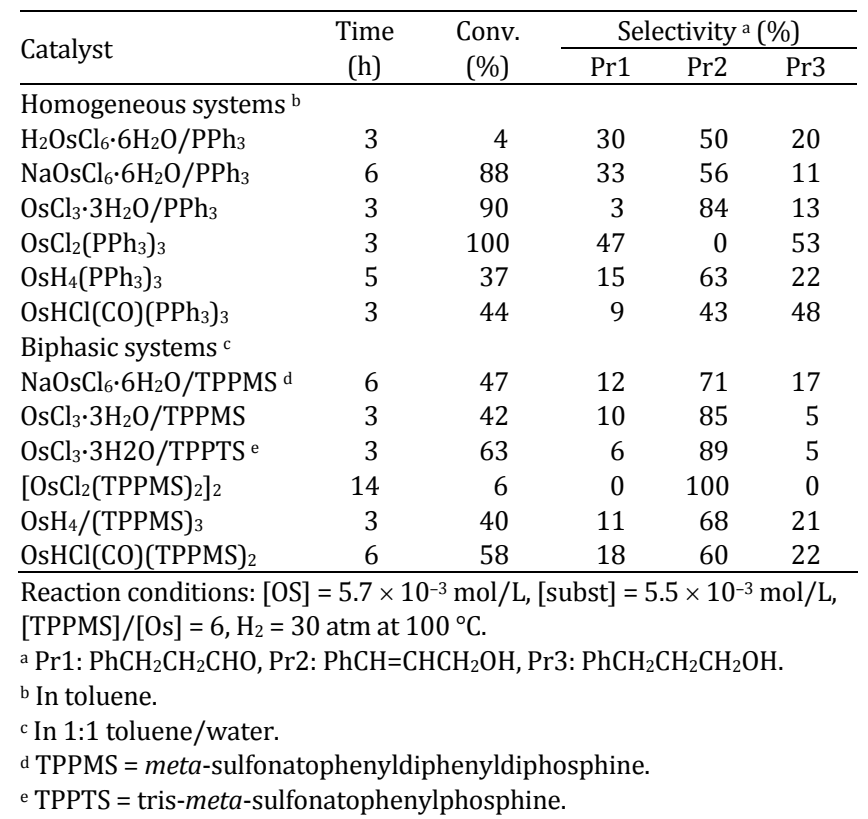




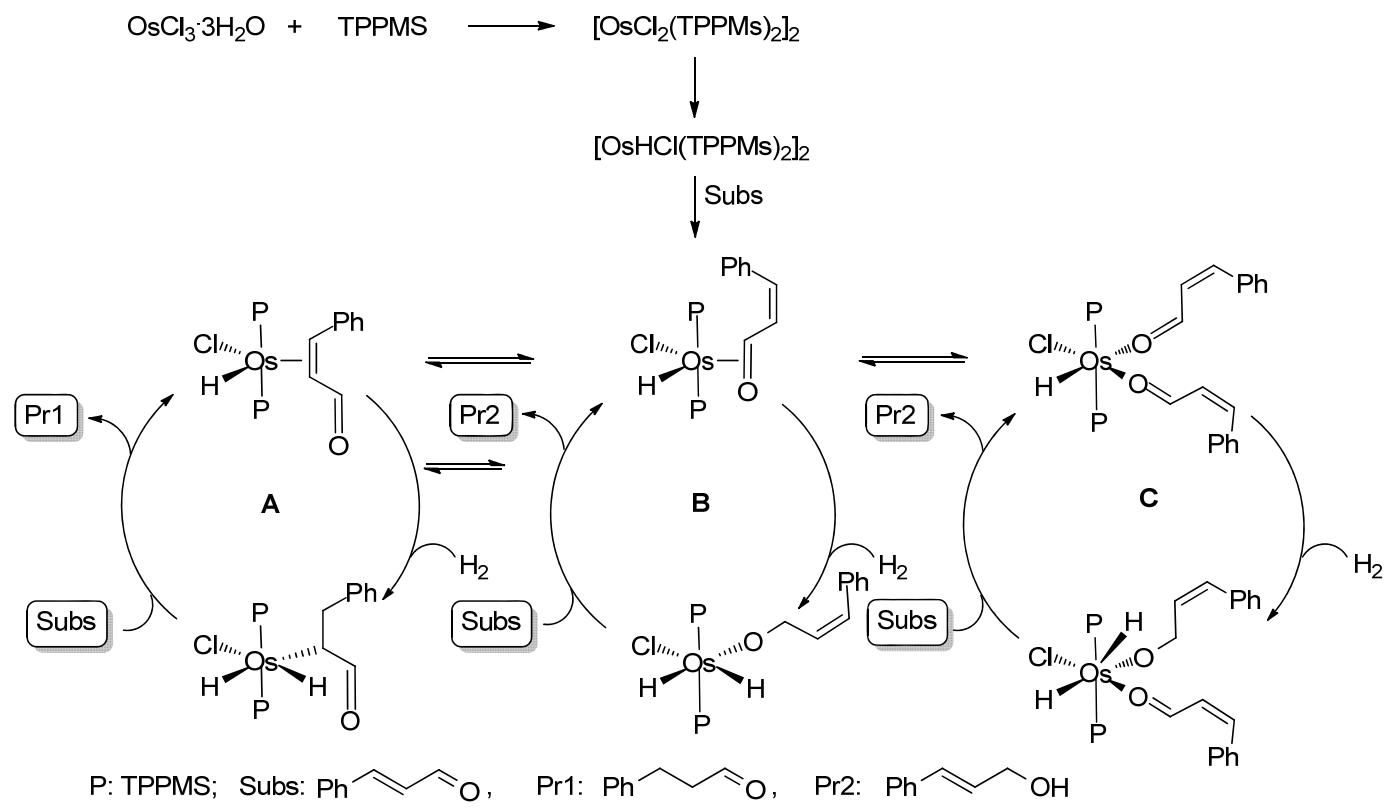

Scheme 17. Proposed mechanism for hydrogenation of cinnamaldehyde with $\mathrm{OsCl}_{3} \cdot 3 \mathrm{H}_{2} \mathrm{O}$ and TPPMS [31].

$\left.\mathrm{P}(\mathrm{OEt})_{3}\right]$. The neutral triazenide complex OsCl( $\eta^{2}-1,3-(p$-tolyl)NNN $p$-tolyl $)\left(\eta^{6}-p\right.$-cymene) (43) was prepared by reacting 39 with 1,3-diaryltriazene in the presence of $\mathrm{NEt}_{3}$. The $p$-cymene complex $39(\mathrm{~L}=\mathrm{CN} t-\mathrm{Bu})$ reacted with an equimolar amount of the triazine $1,3-\mathrm{PhN}=\mathrm{NN}(\mathrm{H}) \mathrm{Ph}$ to give the amine derivative $\left[\mathrm{OsCl}\left(\mathrm{PhNH}_{2}\right)(\eta\right.$ - $p$-cymene $\left.) \mathrm{CN} t-\mathrm{Bu}\right] \mathrm{BPh}_{4}$ (44).

The osmium complexes 41, 42a and b, 43, and 44 were
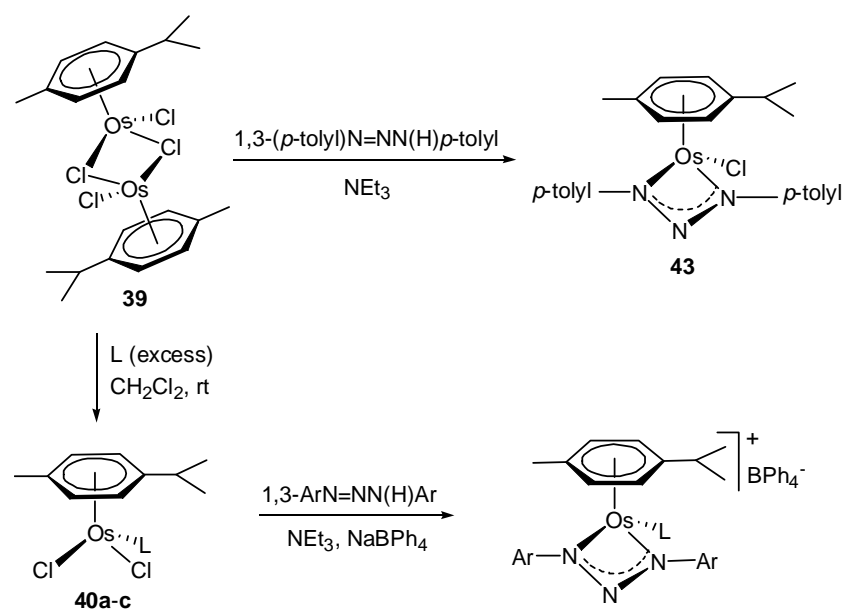

a: $L=P(O E t)_{3}, \quad b: L=P P h(O E t)_{2}$ d: $L=t$-BuNC

$40 \mathrm{~d}$

1,3-PhN=NN(H)Ph, EtOH, $\mathrm{NaBPh}_{4}$

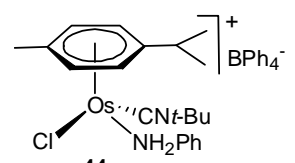

44

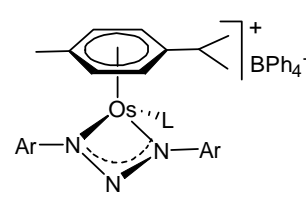

41: $\mathrm{Ar}=\mathrm{Ph}, \mathrm{L}=\mathrm{PPh}(\mathrm{OEt})_{2}$ 42a: $\mathrm{Ar}=p$-tolyl, $\mathrm{L}=\mathrm{P}(\mathrm{OEt})_{3}$ 42b: $\mathrm{Ar}=p$-tolyl, $\mathrm{L}=\mathrm{PPh}(\mathrm{OEt})_{2}$

Scheme 18. Synthesis of osmium complexes 41, 42a and b, 43, and 44 [32]. used in the hydrogenation of styrene under $50 \mathrm{~atm}$ of $\mathrm{H}_{2}$ at $80^{\circ} \mathrm{C}$ for $22 \mathrm{~h}$, with a substrate/catalyst molar ratio of $500 / 1$ [32]. All the catalytic precursors were highly active, affording ethylbenzene in high yields (80\%-100\%; Table 5). 2-Cyclohexen-1-one was also hydrogenated with these catalysts under the same reaction conditions. The cationic complexes 41 and 42a and $b$ gave low substrate conversions and a mixture of cyclohexanone and cyclohexanol, the former being the main reaction product $(80 \%-85 \%)$ (Table 6). The neutral osmium derivative 43, which did not contain a phosphorus ligand, was even less active (10\% conversion) and afforded cyclohexanone as the only product. A better result was achieved by performing the reaction in the presence of the isocyanide derivative $\mathbf{4 4}$, which gave about $77 \%$ substrate conversion. Again, a mixture of cyclohexanone and cyclohexanol was produced and the ketone was the major product (84\%). The catalytic activities of these osmium complexes increased when the reaction temperature was increased to $100{ }^{\circ} \mathrm{C}$. The temperature increase not only led to a substrate conversion of $100 \%$, but also increased hydrogenation of the $\mathrm{C}=0$ bond. All the cationic osmium complexes containing a phosphite ligand afforded cyclohexanol in about $40 \%$ yield (Table 6) and the

\section{Table 5}

Hydrogenation of styrene catalyzed by complexes 41, 42a and b, 43, and 44 [32].

\begin{tabular}{lcc} 
& Complexes $\mathbf{4 1}, \mathbf{4 2 a}, \mathbf{b}, \mathbf{4 3}, \mathbf{4 4}$ \\
\cline { 2 - 3 } $\mathrm{H}_{2}$, toluene, $80-100{ }^{\circ} \mathrm{C}$
\end{tabular}

Reaction conditions: substrate $(2.6 \mathrm{mmol})$, catalyst $(0.0052 \mathrm{mmol})$, toluene (5 mL), $\mathrm{H}_{2}(50 \mathrm{~atm}), 22 \mathrm{~h}$. 
Table 6

Hydrogenation of 2-cyclohexen-1-one catalyzed by complexes $41, \mathbf{4 2 a}$ and $b, 43$, and 44 [32].

\begin{tabular}{|c|c|c|c|c|}
\hline Catalyst & $\begin{array}{c}\text { Temp. } \\
\left({ }^{\circ} \mathrm{C}\right)\end{array}$ & $\begin{array}{c}\text { Conversion } \\
(\%)\end{array}$ & $\begin{array}{c}\text { Cyclohexanone } \\
(\%)\end{array}$ & $\begin{array}{c}\text { Cyclohexanol } \\
(\%) \\
\end{array}$ \\
\hline 41 & 80 & 19 & 88 & 12 \\
\hline 41 & 100 & 100 & 58 & 42 \\
\hline $42 a$ & 80 & 18 & 85 & 15 \\
\hline $42 a$ & 100 & 100 & 61 & 39 \\
\hline $42 b$ & 80 & 21 & 80 & 20 \\
\hline $42 b$ & 100 & 100 & 58 & 42 \\
\hline 43 & 80 & 10 & 100 & - \\
\hline 43 & 100 & 100 & 81 & 29 \\
\hline 44 & 80 & 77 & 84 & 16 \\
\hline 44 & 100 & 100 & - & 100 \\
\hline
\end{tabular}

Reaction conditions: substrate $(2.6 \mathrm{mmol})$, catalyst $(0.0052 \mathrm{mmol})$, toluene ( $5 \mathrm{~mL}), \mathrm{H}_{2}$ (50 atm), $22 \mathrm{~h}$.

most active isocyanide complex, i.e., 44, gave cyclohexanol in $100 \%$ yield. When the osmium-based catalytic precursors $\mathbf{4 1}$, 42a and $b, \mathbf{4 3}$, and $\mathbf{4 4}$ were used to hydrogenate cinnamaldehyde under $50 \mathrm{~atm}$ of $\mathrm{H}_{2}$ at $100{ }^{\circ} \mathrm{C}$ for $22 \mathrm{~h}$, the results were disappointing. In all cases, only 3-phenylpropanal was formed, in negligible amounts $(2 \%-3 \%)$.

Recently, Gusev and coworkers [33] evaluated the osmium-hydride complexes $\mathrm{OsH}_{2}(\mathrm{CO})\left[\mathrm{NH}\left(\mathrm{CH}_{2} \mathrm{Pi}_{-}-\mathrm{Pr}_{2}\right)_{2}\right]$ (45) and OsHCl(CO)[NH( $\left.\left.\mathrm{CH}_{2} \mathrm{Pi}_{-} \mathrm{Pr}_{2}\right)_{2}\right]$ (46) (Fig. 1) in the catalytic hydrogenation to alcohols of hexyl octanoate and cis-3-hexenyl hexanoate, as model substrates for triglycerides. Both complexes achieved full conversion of hexyl octanoate to hexanol under $54 \mathrm{~atm}$ of $\mathrm{H}_{2}$ at $220^{\circ} \mathrm{C}$. However, when the second model substrate, cis-3-hexenyl hexanoate, was used under the optimum reaction conditions, complexes $\mathbf{4 5}$ and $\mathbf{4 6}$ hydrogenated the $\mathrm{C}=\mathrm{C}$ bond, affording hexyl hexanoate as the main product $(97 \%)$ and a small trace of 1 -hexanol $(<3 \%)$, resulting in ineffective reduction of the ester moiety. These results show that these complexes are active and selective catalysts for alkene hydrogenation. The reasons for these results were elucidated using ${ }^{1} \mathrm{H},{ }^{13} \mathrm{C}$, and ${ }^{31} \mathrm{P}$ nuclear magnetic resonance spectroscopy. The spectroscopic information was consistent with reaction of the unsaturated ester with the hydrogenated catalyst $\mathbf{4 5}$, yielding the saturated ester and amido complex 47 , which can then react under catalytic conditions directly with $\mathrm{H}_{2}$, generating 45 and closing the catalytic cycle. Scheme 19 summarizes these reactions.

Phillips and coworkers [34] described the synthesis and catalytic applications of the organoosmium $\beta$-diketiminato complex 48 , which was obtained by treatment of the dichlo-

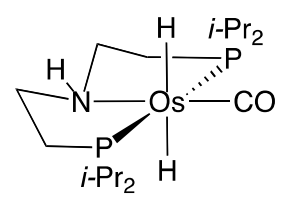

45

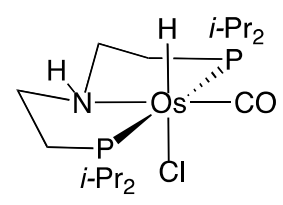

46
Fig. 1. Structures of osmium complexes 45 and 46 [33].

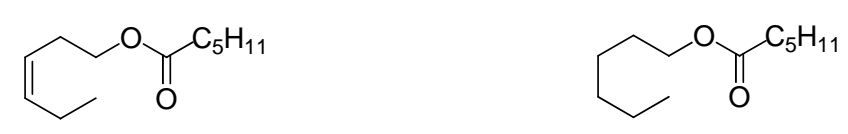<smiles>CC1C(C)C1C</smiles>

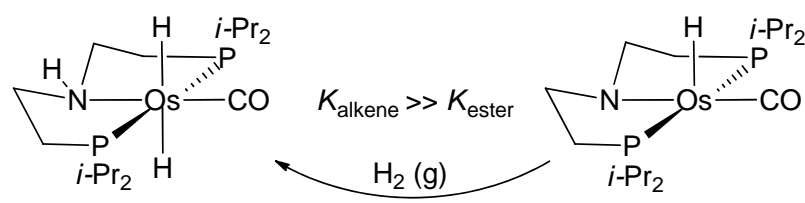

45

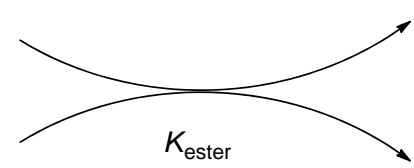

47<smiles>CCCCCCCCCCOC(=O)CCCCC</smiles><smiles>CCCCCCCCCCCO</smiles>

Scheme 19. Proposed catalytic cycle for hydrogenation of hexyl octanoate with osmium complex 45 [33].

dichloro $\left(\eta^{6-} \mathrm{C}_{6} \mathrm{H}_{6}\right)$ osmium(II) dimer $+\mathrm{Li}\left(\left(2,6-\mathrm{Me}_{2} \mathrm{C}_{6} \mathrm{H}_{3} \mathrm{NCMe}\right)_{2} \mathrm{CH}\right)$
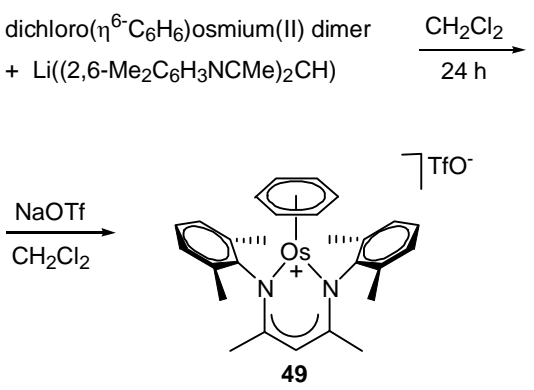

Scheme 20. Synthesis of osmium complexes 48 and 49 [34].

$\operatorname{ro}\left(\eta^{6}-\mathrm{C}_{6} \mathrm{H}_{6}\right)$ osmium(II) dimer with $\mathrm{Li}\left[\left(2,6-\mathrm{Me}_{2} \mathrm{C}_{6} \mathrm{H}_{3} \mathrm{NCMe}\right)_{2} \mathrm{CH}\right]$, and complex 49 , which was formed by reacting 48 with NaOTf (Scheme 20). These complexes were screened for their abilities to mediate the catalytic hydrogenations of various olefins. Complexes 48 [turnover frequency (TOF) = $1842 \mathrm{~h}^{-1}$ ] and 49 ( TOF $=1246 \mathrm{~h}^{-1}$ ) both showed good activity in the hydrogenation of styrene, superior to those of the ruthenium analogs (Table 7). The reduction of cyclohex-1-ene was significantly slower than that of styrene (TOF $=1090-1492 \mathrm{~h}^{-1}$ ). A considerable decrease in the catalytic activity was observed when 1-methylcyclohex-1-ene was used, as a consequence of the increased steric bulk of the substrate (TOF $=66-60 \mathrm{~h}^{-1}$; Table 8). Complexes 48 and 49 gave exclusive exocyclic hydrogenation of limonene, and the osmium complexes were considera-

\section{Table 7}

Hydrogenation of styrene catalyzed by osmium complexes 48 and 49 [34].

\begin{tabular}{|c|c|c|c|}
\hline Catalyst & Time (h) & Conversion (\%) & TOF $\left(\mathrm{h}^{-1}\right)$ \\
\hline 48 & 0.5 & 92 & 1842 \\
\hline 49 & 0.5 & 62 & 1246 \\
\hline
\end{tabular}

Reaction conditions: catalyst ( $0.1 \mathrm{~mol} \%)$, styrene (9.6 mmol), THF (12 $\mathrm{mL}), \mathrm{H}_{2}(40 \mathrm{~atm}), 80^{\circ} \mathrm{C}$. 
Table 8

Hydrogenation of cyclohexene $(\mathrm{R}=\mathrm{H})$ and 1-methylcyclohex-1-ene $(\mathrm{R}=$ $\mathrm{Me}$ ) catalyzed by osmium complexes 48 and 49 [34].

\begin{tabular}{lcccc} 
& & \multicolumn{3}{c}{$c$} \\
\hline Catalyst & $\mathrm{R}$ & $\mathrm{Time}(\mathrm{h})$ & Conversion $(\%)$ & $\mathrm{TOF}\left(\mathrm{h}^{-1}\right)$ \\
\hline $\mathbf{4 8}$ & $\mathrm{H}$ & 0.5 & 55 & 1090 \\
$\mathbf{4 9}$ & $\mathrm{H}$ & 0.5 & 75 & 1492 \\
$\mathbf{4 8}$ & $\mathrm{Me}$ & 1.0 & 7 & 66 \\
$\mathbf{4 9}$ & $\mathrm{Me}$ & 1.0 & 6 & 60 \\
\hline
\end{tabular}

Reaction conditions: catalyst (0.1 mol\%), alkene (10.4-12.2 mmol), THF (12 mL), $\mathrm{H}_{2}(40-50 \mathrm{~atm}), 80^{\circ} \mathrm{C}$.

Table 9

Hydrogenation of limonene catalyzed by osmium complexes 48 and 49 [34].

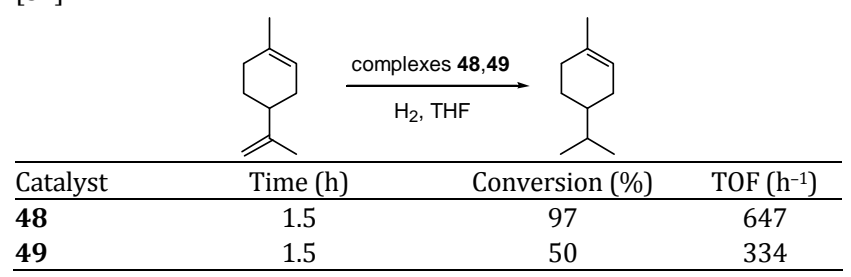

Reaction conditions: catalyst (0.1 mol\%), limonene (9.6 mmol), THF (12 mL), $\mathrm{H}_{2}(40 \mathrm{~atm}), 80^{\circ} \mathrm{C}$.

bly more active than their ruthenium counterparts (Table 9). This was the first report of the osmium-catalyzed hydrogenation of limonene.

\section{Clusters}

A number of osmium carbonyl clusters have been synthesized and used as catalysts in the isomerization and hydrogenation of $\mathrm{C}=\mathrm{C}$ bonds [35].

Ferrari et al. [36] reported that the trinuclear cluster $\mathrm{Os}_{3}(\mathrm{CO})_{12}$ in toluene catalyzed the isomerization of linear mono-olefins such as pentenes and hexanes at $110-120{ }^{\circ} \mathrm{C}$. Pent-1-ene gave 2-cis- and 2-trans-pentene in an initial ratio of 0.4-0.5, but reliable values for the initial isomerization rate could not be obtained because carbonyl complexes were formed when the conversion of pent-1-ene began to be detectable.

The use of osmium clusters as catalysts poses the question whether the cluster itself or a cluster fragment is the catalytically active species. Detailed mechanistic studies were performed to clarify this point.

Keister et al. [37] reported that the unsaturated dihydro derivative $\mathrm{H}_{2} \mathrm{Os}_{3}(\mathrm{CO})_{10}$ hydrogenated olefins in solution. The reaction of this osmium complex with 100 equiv. of hex-1-ene under $3.4 \mathrm{~atm}$ of $\mathrm{H}_{2}$ at $50^{\circ} \mathrm{C}$ in octane for $35 \mathrm{~h}$ gave 31 equiv. of hexane and 69 equiv. of internal hexenes. All the catalyst was recovered at the end of the reaction. The high degree of isomerization indicated reversibility of the insertion and coordination steps, whereas buildup of internal hexenes is consistent with the observed failure of $\mathrm{H}_{2} \mathrm{Os}_{3}(\mathrm{CO})_{10}$ to hydrogenate other internal alkenes such as cyclooctene. A combination of chemical and spectroscopic methods was used to establish the catalytic cycle, and showed that only trinuclear species were present throughout the hydrogenation process (Scheme 21). The key

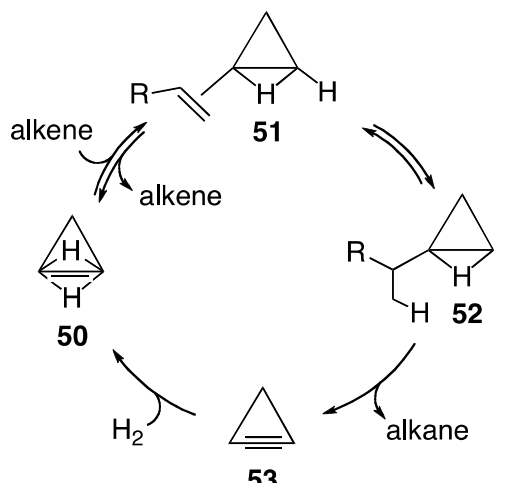

alkene

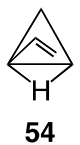

Scheme 21. Scheme for reaction of $\mathrm{H}_{2} \mathrm{Os}_{3}(\mathrm{CO})_{10}$ (50) with alkenes, involving $\mathrm{HOs}_{3}(\mathrm{CO})_{10}$ (alkene) (51), $\mathrm{HOs}_{3}(\mathrm{CO})_{10}$ (alkyl) (52), $\mathrm{Os}_{10}(\mathrm{CO})_{10}$ (53), and $\mathrm{HOs}_{3}(\mathrm{CO})_{10}$ (alkenyl) (54) [37].

presumed intermediate in this scheme is the highly unsaturated 44-electron species $\mathrm{Os}_{3}(\mathrm{CO})_{10}$ (53), which reacts with $\mathrm{H}-\mathrm{H}$ or vinylic $\mathrm{C}-\mathrm{H}$ bonds, if available, or decomposes via other, unknown, pathways.

Basset and coworkers [38,39] reported that the closely related silica-supported cluster $\mathrm{Os}_{3}(\mathrm{CO})_{10}(\mu-\mathrm{H})(\mu-\mathrm{OSi} \equiv)(\mathbf{5 5})$ was an efficient catalyst for ethylene hydrogenation using an ethylene and $\mathrm{H}_{2}$ (1:10) mixture at $80{ }^{\circ} \mathrm{C}$ in a closed vessel. Several hydrogenation runs gave about $100 \%$ ethylene conversion without any appreciable loss in catalytic activity and apparent changes in the spectroscopic properties of the catalyst. The nature of the active species and the elementary steps involved in the hydrogenation reaction were established based on kinetic and mechanistic studies of cluster $\mathbf{5 5}$, and the soluble model compound $\mathrm{Os}_{3}(\mathrm{CO})_{10}(\mu-\mathrm{H})(\mu-\mathrm{OPh})(56)$. Kinetic (hydrogenation was zero order in ethylene and first order in $\mathrm{H}_{2}$ ), volumetric, and IR spectroscopic studies of the reaction of $\mathbf{5 5}$ with ethylene, $\mathrm{H}_{2}$, and $\mathrm{CO}$ indicated a mechanism involving the intact triosmium framework in all the elementary steps, supporting the catalytic cycle shown in Scheme 22. The facile $3 \mathrm{e} \rightleftharpoons$ 1e interconversion of surface oxygen ligands provided an appropriate energy balance for cluster catalysis without fragmentation. The reactivity of $\mathbf{5 6}$ toward ethylene and $\mathrm{H}_{2}$ was also studied using IR and NMR spectroscopies. The results were in agreement with the hydrogenation cycle proposed for $\mathbf{5 5 .}$ However, in contrast to 55, compound $\mathbf{5 6}$ was quickly transformed in solution under catalytic conditions, with loss of phenol and formation of $\mathrm{H}_{2} \mathrm{Os}_{3}(\mathrm{CO})_{10}$ and $\mathrm{H}_{4} \mathrm{Os}_{4}(\mathrm{CO})_{12}$. This different behavior indicated stabilization by the silica support.

Sánchez-Delgado and coworkers [40] investigated the catalytic potential of tri- and tetra-nuclear osmium clusters using the hydrogenation of cyclohexene under $30 \mathrm{~atm}$ of $\mathrm{H}_{2}$ at 100 and $150{ }^{\circ} \mathrm{C}$ as model reactions (Table 10). The following possible correlations between the catalytic behavior and metal framework structure were proposed. (1) Trinuclear and tetra- 


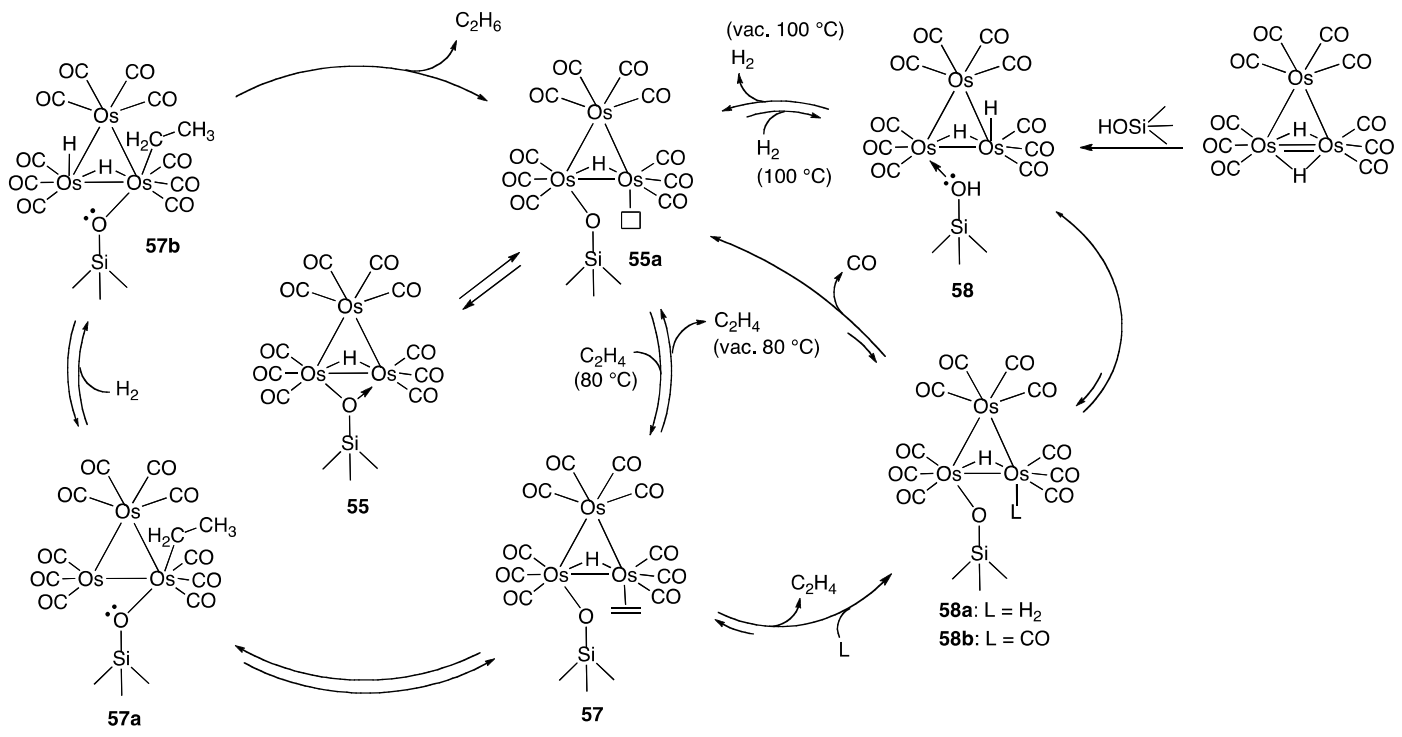

Scheme 22. Proposed catalytic cycle for hydrogenation of ethylene with osmium complex $\mathbf{5 5}$ [38,39].

nuclear osmium clusters are efficient catalyst precursors for olefin hydrogenation under moderate reaction conditions, affording appreciable conversions to cyclohexane. (2) The thermal stability is an important factor in the catalytic behaviors of the $\mathrm{Os}_{3}$ and $\mathrm{Os}_{4}$ cluster units; the more fragile clusters tend to rearrange to the more stable tetranuclear structure $\mathrm{H}_{4} \mathrm{Os}_{4}(\mathrm{CO})_{12}$. (3) Coordinatively unsaturated "open" structures, if thermally stable (e.g., $\left.\mathrm{H}_{3} \mathrm{Os}_{4}(\mathrm{CO})_{12} \mathrm{I}\right)$, have higher catalytic activities than "closed" saturated species (e.g., $\mathrm{H}_{4} \mathrm{Os}_{4}(\mathrm{CO})_{12}$ ). The increased stability and reactivity are, in this particular case, probably related to the presence of an iodine ligand. (4) For any one structure, anionic clusters tend to be more active than their neutral analogs.

Another system that appears to hydrogenate olefins via a cycle involving only trinuclear species is the osmium complex PPN [Os3(NCO)(CO) $\left.{ }_{11}\right]$ [PPN = bis(tripheny1phosphine)iminium cation] (59), which hydrogenated maleic anhydride at $60^{\circ} \mathrm{C}$ and $3.4 \mathrm{~atm}$ of $\mathrm{H}_{2}$ to afford succinic anhydride after $24 \mathrm{~h}$ [41]. Analogously, 3,3-dimethylbutene was hydrogenated at $78{ }^{\circ} \mathrm{C}$

\section{Table 10}

Hydrogenation of cyclohexene with osmium complexes [40].

\begin{tabular}{|c|c|c|c|}
\hline \multirow{2}{*}{ Complex } & \multirow{2}{*}{$\begin{array}{c}\text { Metal } \\
\text { framework }\end{array}$} & \multicolumn{2}{|c|}{ Turnover number a } \\
\hline & & $100^{\circ} \mathrm{C}$ & $150^{\circ} \mathrm{C}$ \\
\hline $\mathrm{Os}_{3}(\mathrm{CO})_{12}$ & $\Delta$ & 70 & 400 \\
\hline$\left[\mathrm{HOs}_{3}(\mathrm{CO})_{11}\right][\mathrm{PPN}]$ & & 10 & 30 \\
\hline $\mathrm{H}_{4} \mathrm{Os}_{4}(\mathrm{CO})_{12}$ & & 30 & 610 \\
\hline$\left[\mathrm{H}_{3} \mathrm{Os}_{4}(\mathrm{CO})_{12}\right][\mathrm{PPN}]$ & & 340 & 80 \\
\hline $\mathrm{H}_{3} \mathrm{Os}_{4}(\mathrm{CO})_{12} \mathrm{I}$ & & 0 & 880 \\
\hline $\mathrm{H}_{3} \mathrm{Os}_{4}(\mathrm{CO})_{12}(\mathrm{NO})$ & & 160 & 480 \\
\hline$\left.\left[\mathrm{H}_{3} \mathrm{Os}_{4}(\mathrm{CO})_{12}(\mathrm{MeCN})_{2}\right)\right]\left[\mathrm{BF}_{4}\right]$ & & 200 & 630 \\
\hline
\end{tabular}

a Mol product/mol complex. within $24 \mathrm{~h}$. Spectroscopic studies of the chemical reactions involved with $\mathbf{5 9}$ provided evidence for the intermediates shown in the catalytic cycle proposed in Scheme 23, in which the $\mu-\eta^{2} \rightleftharpoons \eta^{1}$ transformation of the isocyanate ligand provides the vacant coordination site required for catalysis to proceed, without the need to break any Os-Os bonds.

Styrene hydrogenation was efficiently catalyzed by the tetranuclear osmium complexes $\mathrm{H}_{3} \mathrm{Os}_{4}(\mathrm{CO})_{12}(\mathrm{I})$ (60), $\mathrm{H}_{4} \mathrm{Os}_{4}(\mathrm{CO})_{12}(\mathbf{6 1})$, $\left[\mathrm{H}_{2} \mathrm{Os}_{4}(\mathrm{CO})_{12}(\mathrm{I})\right]^{-}(\mathbf{6 2})$, and $\left[\mathrm{H}_{3} \mathrm{Os} \mathrm{s}_{4}(\mathrm{CO})_{12}\right]^{-}$ (63) in decalin solution at $140{ }^{\circ} \mathrm{C}$ and $1.05 \mathrm{~atm}$ of $\mathrm{H}_{2}$ [42]. The activity of the butterfly-shaped cluster 60 was considerably higher than those of the tetrahedral species 61-64. This would be expected to be the case if the integrity of the clusters is maintained during catalysis because a butterfly metal frame-
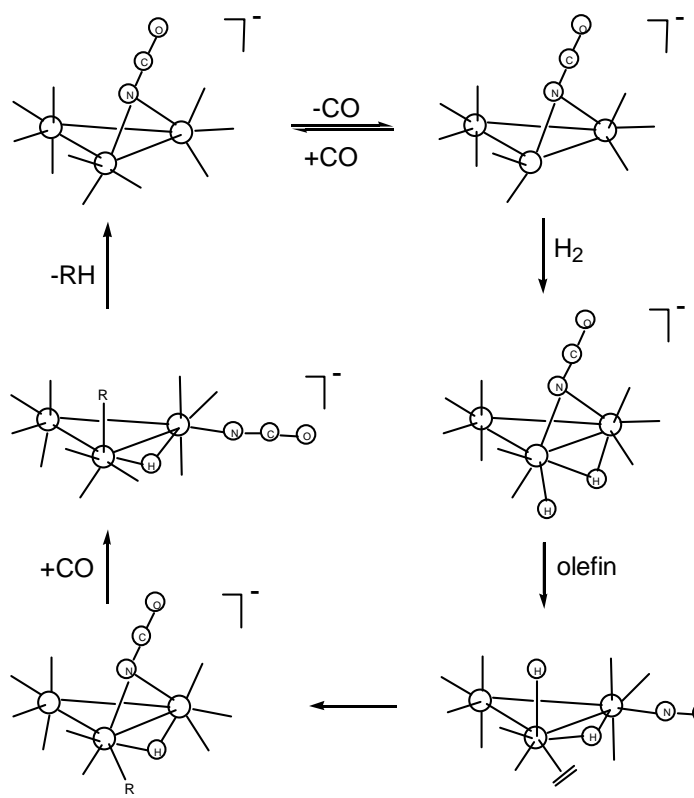

Scheme 23. Proposed catalytic cycle for hydrogenation of maleic anhydride with osmium complex 59 [41]. 


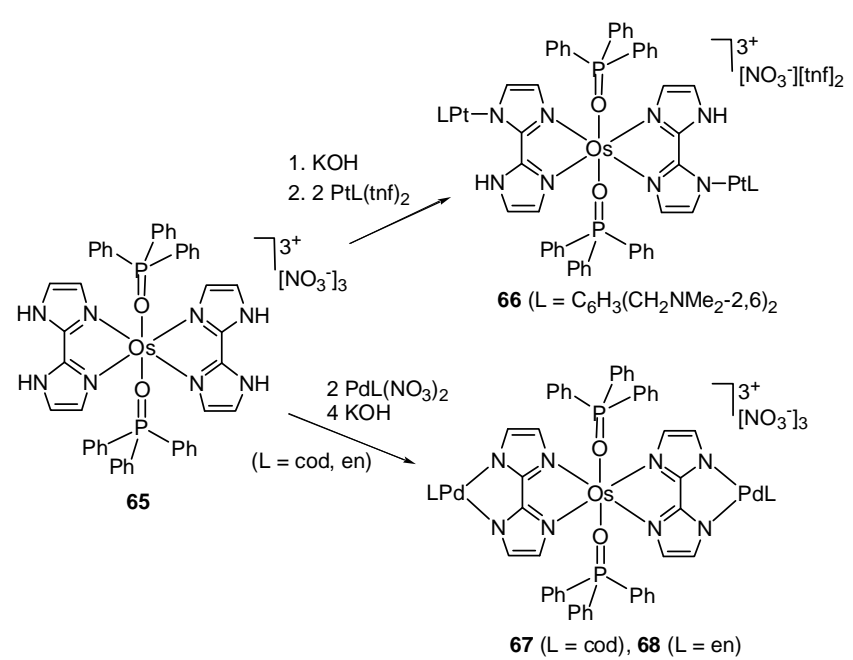

Scheme 24. Synthesis of osmium complexes 66-68 from osmium complex 65 [41].

work is electronically less saturated than a tetrahedral arrangement. However, kinetic (the reaction rate depended on the cluster structure and was first order with respect to the concentrations of styrene and $\mathrm{H}_{2}$, and the TOF increased with decreasing cluster concentration), spectroscopic, and other results indicated that tetranuclear osmium clusters were not directly involved in the catalytic cycle, but probably underwent fragmentation to produce low concentrations of species of lower nuclearity (perhaps mononuclear), which were responsible for the observed activity.

Comba and coworkers [43] reported the synthesis and characterization of trinuclear $\mathrm{Pt}(\mathrm{II})-\mathrm{Os}(\mathrm{III})-\mathrm{Pt}(\mathrm{II})$ and Pd(II)-Os(III)-Pd(II) complexes, with 2,2'-biimidazolate $\left(\right.$ Hbiim $^{-}$, biim $\left.^{2-}\right)$ as bridging ligands. The mononuclear osmium(III) complex $\left[\mathrm{Os}\left(\mathrm{H}_{2} \text { biim }\right)_{2}\left(\mathrm{O}=\mathrm{PPh}_{3}\right)_{2}\right]\left(\mathrm{NO}_{3}\right)_{3}$ (65) [44], used as the starting material, was deprotonated by $\mathrm{KOH}$, affording $\left[\mathrm{Os}(\mathrm{Hbiim})_{2}\left(\mathrm{O}=\mathrm{PPh}_{3}\right)_{2}\right]\left(\mathrm{NO}_{3}\right)$ and $\left[\mathrm{Os}(\text { biim })_{2}\left(\mathrm{O}=\mathrm{PPh}_{3}\right)_{2}\right]^{-}$, which smoothly reacted with various transition-metal complexes, producing the trimetallic $\mathrm{OsPt}_{2}$ and $\mathrm{OsPd}_{2}$ complexes 66-68 in high yields (Scheme 24). The catalytic properties of complexes 66-68 were investigated based on homogeneous hydrogenation of hex-1-ene and cyclohexene in dichloromethane solution at $25{ }^{\circ} \mathrm{C}$ under $5 \mathrm{~atm}$ of $\mathrm{H}_{2}$. Low catalytic activities were ob-
Table 11

Hydrogenation of hex-1-ene and cyclohexene with osmium complexes 65-68 [43].

\begin{tabular}{lrrrrr}
\hline \multirow{2}{*}{ Catalyst } & \multicolumn{2}{c}{ 1-Hexene } & & \multicolumn{2}{c}{ Cyclohexene } \\
\cline { 2 - 3 } \cline { 5 - 6 } & Time $(\mathrm{h})$ & Hexane $(\%)$ & & Time $(\mathrm{h})$ & Cyclohexane (\%) \\
\hline $\mathbf{6 5}$ & 10 & 11 & & 10 & 0 \\
$\mathbf{6 6}$ & 5 & 7 & & 5 & 3 \\
$\mathbf{6 7}$ & 10 & 53 & & 10 & 36 \\
$\mathbf{6 8}$ & 5 & 15 & & 5 & 10 \\
\hline
\end{tabular}

Reaction conditions: 1-hexene and cyclohexene in $\mathrm{CH}_{2} \mathrm{Cl}_{2}$ solutions at $25^{\circ} \mathrm{C}, \mathrm{H}_{2}(5 \mathrm{~atm})$.

served with these complexes, being 67 the most active catalyst in the series (Table 11).

\section{Conclusions}

In this review, we have described the evolution of osmium complexes as catalysts in the hydrogenation and isomerization of alkenes. Some of the examples reported here show that the activities and selectivities of osmium complexes in such catalytic processes were initially relatively low, but have increased to useful levels. However, it should be noted that, despite the growing number of reports on the use of osmium complexes in catalysis, examples of these processes are still limited. Studies have so far mostly concentrated on simple model substrates, and therefore reactions involving sophisticated organic molecules need to be explored. Moreover, there are no reported examples of stereoselective alkene reductions using osmium complexes. The development of new osmium complexes or improvement of the existing ones is certainly of great interest in the search for new methods for the catalytic hydrogenation and isomerization of alkenes.

\section{References}

[1] R. H. Morris, Ruthenium and Osmium, in: The Handbook of Homogeneous Hydrogenation, J. G. de Vries, C. J. Elsevier, eds, Wiley-VCH, Weinheim, 2008, 45-70.

[2] R. A. Sánchez-Delgado, M. Rosales, M. A. Esteruelas, L. A. Oro, J. Mol. Catal. A, 1995, 96, 231-243.

[3] G. Chelucci, S. Baldino, W. Baratta, Acc. Chem. Res., 2015, 48,

\section{Graphical Abstract}

Chin. J. Catal., 2016, 37: 1824-1836 doi: 10.1016/S1872-2067(16)62542-1

\section{Osmium complexes in catalysis of olefin hydrogenation and isomerization}

Giorgio Chelucci *, Gérard A. Pinna, Giansalvo Pinna, Maurizio Solinas, Barbara Sechi Università di Sassari, Italy

This review describes the evolution of the use of osmium complexes as catalysts in the hydrogenation and isomerization of olefins. The examples reported show that osmium systems show good catalytic activities and selectivities in both dihydrogen and

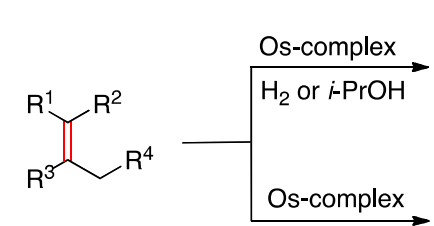
$\mathrm{C}^{\mathrm{R}^{1} \mathrm{R}^{4}}$

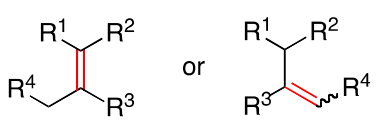
transfer hydrogenation. 
363-379.

[4] G. Chelucci, S. Baldino, W. Baratta, Coord. Chem. Rev., 2015, 300, 29-85.

[5] L. Vaska, Inorg. Nucl. Chem. Lett., 1965, 1, 89-95.

[6] T. R. B.Mitchell, J. Chem. Soc. B, 1970, 823-825.

[7] B. Bell, J. Chatt, G. J. Leigh, J. Chem. Soc., Dalton Trans., 1973, 997-1004.

[8] R. A. Sánchez-Delgado, A. Andriollo, N. Valencia, J. Chem. Soc., Chem. Commun., 1983, 444-445.

[9] L. Vaska, J. Am. Chem. Soc., 1964, 86, 1943-1950.

[10] R. A. Sánchez-Delgado, A. Andriollo, E. Gonzalez, N. Valencia, V. León, J. Espidel, J. Chem. Soc., Dalton Trans., 1985, 1859-1863.

[11] R. A. Sánchez-Delgado, A. Andriollo, N. Valencia, J. Mol. Catal,, 1984, 24, 217-220.

[12] M. Rosales, A. González, J. Navarro, H. Soscún, J. Zárraga, Inorg. Chim. Acta, 1997, 257, 131-135.

[13] M. Rosales, A. González, M. Mora, N. Nader, J. Navarro, L. Sánchez, H. Soscún, Transition Metal Chem., 2004, 29, 205-211.

[14] M. Rosales, Y. Alvarado, N. Gallardo, R. Rubio, Transition Metal Chem., 1995, 20, 242-245.

[15] M. A. Esteruelas, H. Werner, J. Organomet. Chem., 1986, 303, 221-231.

[16] M. A. Esteruelas, E. Sola, L. A. Oro, H. Werner, U. Meyer, J. Mol. Catal., 1988, 45, 1-5.

[17] A. Andriollo, M. A. Esteruelas, U. Meyer, L. A. Oro, R. A. Sánchez-Delgado, E. Sola, C. Valero, H. Werner, J. Am. Chem. Soc., 1989, 111, 7431-7437.

[18] M. Aracama, M. A. Estemelas, F. J. Lahoz, J. A. Lopez, U. Meyer, L. A. Oro, H. Werner, Inorg. Chem., 1991, 30, 288-293.

[19] C. Bianchini, E. Farnetti, M. Graziani, M. Peruzzini, A. Polotts, Organometallics, 1993, 12, 3753-3761.

[20] T. F. Mao, G. L. Rempel, J. Mol. Catal. A, 2000, 153, 63-73.

[21] G. L. Rempel, N. T. McManus, J. S. Parent, US Patent 5561197, 1996.

[22] J. S. Parent, Catalytic Hydrogenation of Butadiene Copolymers. Ph.D. Thesis, University of Waterloo, Waterloo, Ontario, Canada, 1996.

[23] J. S. Parent, N. T. McManus, G. L. Rempel, Ind. Eng. Chem. Res., 1996, 35, 4417-4423.

[24] P. Martin, N. T. McManus, G. L. Rempel, J. Mol. Catal. A, 1997, 126,
$115-131$

[25] J. S. Parent, N. T. McManus, G. L. Rempel, Ind. Eng. Chem. Res., 1998, 37, 4253-4261.

[26] J. S. Parent, N. T. McManus, G. L. Rempel, W. P. Power, T. B. Marder, J. Mol. Catal. A, 1998, 135, 285-293.

[27] K. Charmondusit, P. Prasassarakich, N. T. McManus, G. L. Rempel, J. Appl. Polym. Sci., 2003, 89, 142-152.

[28] N. Hinchiranan, P. Prasassarakich, G. L. Rempel, J. Appl. Polym. Sci., 2006, 100, 4499-4514.

[29] A. Mahittikul, P. Prasassarakich, G. L. Rempel, J. Appl. Polym. Sci., 2006, 100, 640-655.

[30] S. Kongparakul, P. Prasassarakich, G. L. Rempel, Eur. Polymer J., 2009, 45, 2358-2373.

[31] R. A. Sànchez-Delgado, M. Medina, F. López-Linares, A. Fuentes, J. Mol. Catal. A, 1997, 116, 167-177.

[32] G. Albertin, S. Antoniutti, J. Castro, S. Paganelli, J. Organomet. Chem., 2010, 695, 2142-2152.

[33] A. Acosta-Ramirez, M. Bertoli, D. G. Gusev, M. Schlaf, Green Chem., 2012, 14, 1178-1188.

[34] D. F. Schreiber, C. O'Connor, C. Grave, H. Müller-Bunz, R. Scopelliti, P. J. Dyson, A. D. Phillips, Organometallics, 2013, 32, 7345-7356.

[35] A. Kulkarni, R. J. Lobo-Lapidus, B. C. Gates, Chem. Commun., 2010, 46, 5997-6015.

[36] R. P. Ferrari, G. A. Vaglio, Inorg. Chim. Acta, 1976, 20, 141-143.

[37] J. B. Keister, J. R. Shapley, J. Am. Chem. Soc., 1976, 98, 1056-1057.

[38] A. Choplin, B. Besson, L. D’Omelas, R. Sánchez-Delgado, J. M. Basset, J. Am. Chem. Soc., 1988, 110, 2783-2787.

[39] B. Besson, A. Choplin, L. D'Omelas, J. M. Basset, J. Chem. Soc., Chem. Commun., 1982, 843-845.

[40] R. A. Sánchez-Delgado, J. Puga, M. Rosales, J. Mol. Catal., 1984, 24, 221-225.

[41] J. L. Zuffa, W. L. Gladfelter, J. Am. Chem. Soc., 1986, 108, 4669-4671.

[42] R. A. Sánchez-Delgado, A. Andriollo, J. Puga, G. Martin, Inorg. Chem., 1987, 26, 1867-1870.

[43] A. Mayboroda, P. Comba, H. Pritzkow, G. Rheinwald, H. Lang, G. van Koten, Eur. J. Inorg. Chem., 2003, 1703-1710.

[44] A. Mayboroda, G. Rheinwald, H. Lang, Eur. J. Inorg. Chem., 2001, 2263-2269.

\title{
Os络合物催化烯烃加氢和异构化反应
}

\author{
Giorgio Chelucci $^{\mathrm{a},{ }^{*}}$, Gérard A. Pinna ${ }^{\mathrm{b}}$, Giansalvo Pinna ${ }^{\mathrm{b}}$, Maurizio Solinas ${ }^{\mathrm{c}}$, Barbara Sechi ${ }^{\mathrm{c}}$ \\ a意大利萨萨里大学农业系, 萨萨里I-07100, 意大利 \\ $\mathrm{b}^{\mathrm{⿱⿱亠䒑}} \mathrm{s}$ 大利萨萨里大学化学与药学系, 萨萨里07100, 意大利 \\ ' 意大利生物化学研究所, 萨萨里I-07100, 意大利
}

摘要: 综述了近年来锇络合物用于催化烯烃加氢和异构化反应的研究进展. Os催化剂在 $\mathrm{H}_{2}$ 分子和转移加氢二个方面用于 烯烃加氢反应均表现出较高的活性和选择性. 因此它有望成为有机合成中的一个强有力的工具.

关键词: 锇络合物; 加氢; 转移加氢; 烯烃异构化

收稿日期: 2016-07-25. 接受日期: 2016-8-18. 出版日期: 2016-11-05.

*通讯联系人. 电话: +39-079-229539; 传真: +39-079-229559; 电子信箱: chelucci@uniss.it

本文的英文电子版由Elsevier出版社在ScienceDirect上出版(http://www.sciencedirect.com/science/journal/18722067). 